Supplementary Information

\title{
Hexavanadate-Organogold(I) Hybrid Compounds: Synthesis by the Azide-Alkyne Cycloaddition and Density Functional Theory Study of an Intriguing Electron Density Distribution
}

Stanislav K. Petrovskii, ${ }^{a}$ Viktoria V. Khistiaeva ${ }^{\mathrm{a}, \mathrm{b}}$ Anastasia A. Sizova, ${ }^{a}$ Vladimir V. Sizov, ${ }^{\mathrm{a}}$ Aleksandra V. Paderina, ${ }^{\mathrm{a}}$ Igor O. Koshevoy, ${ }^{\mathrm{b}}$ Kirill Yu. Monakhov, ${ }^{\mathrm{c}^{*}}$ and Elena V. Grachova ${ }^{\mathrm{a}^{*}}$

a Institute of Chemistry, St. Petersburg State University, Universitetskii pr. 26, 198504 St. Petersburg, Russia

${ }^{b}$ Department of Chemistry, University of Eastern Finland, 80101 Joensuu, Finland

${ }^{c}$ Leibniz Institute of Surface Engineering (IOM), Permoserstraße 15, 04318 Leipzig, Germany

E-mails:

e.grachova@spbu.ru

kirill.monakhov@iom-leipzig.de 


\section{Content}

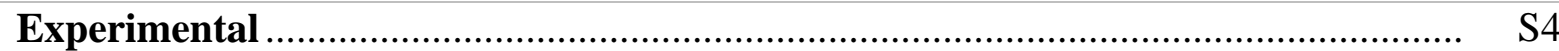

General remarks, materials and instruments ..................................... S4

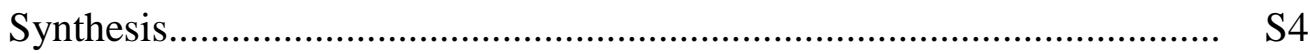

DFT calculations …................................................................. S7

Scheme S1 Atom numeration for assignment of the signals in ${ }^{1} \mathrm{H}$ and ${ }^{13} \mathrm{C}$ NMR spectra for hybrids $\mathbf{P O M}_{\mathbf{N}}^{\mathrm{Au}}$ (left) and $\mathbf{P O M}_{\mathbf{N}}^{\mathrm{Au}}$ (right)....................... S6

Figure S1 $\quad{ }^{1}$ H NMR spectra of $\mathbf{P O M}_{\mathbf{N}}^{\mathbf{A u}}$ (top) and $\mathbf{P O M}_{\mathbf{C}}^{\mathbf{A u}}$ (bottom), DMSO-d $\mathrm{d}_{6}$, r.t... $\quad$ S8

Figure S2 ${ }^{13} \mathrm{C}\left\{{ }^{1} \mathrm{H}\right\}$ (top) and HSQC (bottom) NMR spectra of $\mathbf{P O M}_{\mathbf{N}}^{\mathbf{A u}}$, DMSO-d 6 , r.t.

Figure S3 ${ }^{13} \mathrm{C}\left\{{ }^{1} \mathrm{H}\right\}$ (top) and HSQC (bottom) NMR spectra of $\mathbf{P O M}_{\mathbf{C}}^{\mathrm{Au}}$, DMSO-d 6 , r.t.

Figure S4 ESI-MS of $\mathbf{P O M}_{\mathbf{N}}^{\mathrm{Au}}$ : experimental spectrum and simulated isotopic patterns for the dominating signals.

Figure S5 ESI-MS of $\mathbf{P O M}_{\mathbf{C}}^{\mathbf{A u}}$ : experimental spectrum and simulated isotopic patterns for the dominating signals

Figure S6 FTIR spectra of $\mathbf{P O M}_{\mathbf{N}}$ and $\mathbf{P O} \mathbf{M}_{\mathbf{N}}^{\mathbf{A u}}$ in the fingerprint region, $\mathrm{KBr}$. S13

Figure S7 FTIR spectra of $\mathbf{P O} \mathbf{M}_{\mathbf{C}}$ and $\mathbf{P O} \mathbf{M}_{\mathbf{C}}^{\mathbf{A u}}$ in the fingerprint region, $\mathrm{KBr}$. $\mathrm{S} 13$

Figure S8 Minimum energy structure of hybrid $\mathbf{P O M}_{\mathbf{N}}^{\mathrm{Au}}$ S14

Figure S9 Minimum energy structure of hybrid $\mathbf{P O} \mathbf{M}_{\mathbf{C}}^{\mathrm{Au}}$. S14

Table S1 Calculated $\left(\mathbf{P O M}_{\mathbf{N}}^{\mathrm{Au}}, \mathbf{P O M}_{\mathbf{C}}^{\mathrm{Au}}\right)$ and experimental $\left(\mathbf{P O M}_{\mathbf{N}}, \mathbf{P O M}_{\mathbf{C}}\right)$ bond lengths $(\AA) \mathrm{V}-\mathrm{O}$ and $\mathrm{O}-\mathrm{C}$ in the hexavanadate core.

Figure S10 Charge redistribution in the junction region upon formation of $\mathbf{P O M}_{\mathbf{N}}^{\mathrm{Au}}$ hybrid.

Figure S11 Charge redistribution in the junction region upon formation of $\mathbf{P O M}_{\mathbf{C}}^{\mathrm{Au}}$ hybrid.

Figure S12 Molecular orbitals of $\mathbf{P O M}_{\mathbf{N}}^{\mathrm{Au}}$ and of $\mathbf{P O} \mathbf{M}_{\mathbf{C}}^{\mathrm{Au}}$.

Figure S13 UV/Vis absorption spectra of $\mathbf{P O M}_{\mathbf{N}}^{\mathbf{A u}}$ and $\mathbf{P O M}_{\mathbf{C}}^{\mathbf{A u}}$ hybrids and their 'building blocks'.

Figure S14 Evolution of the $\mathbf{P O M}_{\mathbf{N}}^{\text {Au }}$ hybrid anion structure under 'step-by-step' reduction.

Figure S15 Evolution of the $\mathbf{P O M}_{\mathbf{C}}^{\mathrm{Au}}$ hybrid anion structure under 'step-by-step' reduction. 
Figure S16 Cyclic voltammograms of $\mathbf{P O M}_{\mathbf{N}}^{\mathrm{Au}}$ and $\mathbf{P O M}_{\mathbf{C}}^{\mathrm{Au}}$ hybrids..................... S22

Table S2 Details of cyclic voltammogram measurements of $\mathbf{P O M}_{\mathbf{N}}^{\mathrm{Au}}$ and $\mathbf{P O} \mathbf{M}_{\mathbf{C}}^{\mathrm{Au}}$

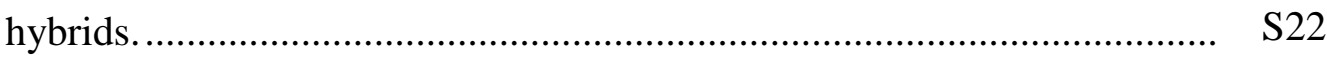




\section{Experimental}

\section{General remarks, materials and instruments}

All manipulations were carried out under argon using standard Schleck technique. Starting materials were used from commercial sources as received. All solvents used for the synthesis were purified according to literature protocols. ${ }^{1}[\mathrm{Au}(\mathrm{tht}) \mathrm{Cl}]$ was synthesized according to a published method. ${ }^{2}$ The solution ${ }^{1} \mathrm{H},{ }^{13} \mathrm{C}\left\{{ }^{1} \mathrm{H}\right\},{ }^{31} \mathrm{P}\left\{{ }^{1} \mathrm{H}\right\}$ and ${ }^{51} \mathrm{~V}$ NMR spectra were recorded on a Bruker $400 \mathrm{MHz}$ Avance spectrometer. Mass spectra were measured on a LC/MS hybrid ultrahigh resolution electrospray quadrupole time-of-flight (UHR ESI-q-TOF) mass spectrometer Bruker MaXis 4G in the $\mathrm{ESI}^{-}$mode. Fourier transform infrared spectra (FTIR) were measured on a Shimadzu IRAffinity spectrometer. UV/Vis absorption spectra were measured using Shimadzu UV-1800 spectrometer in $1 \mathrm{~cm}$ quartz cuvettes. Microanalyses were carried out in the analytical laboratory of the University of Eastern Finland using vario MICRO cube CHNS analyzer (Elementar, Germany).

\section{Synthesis}

[(( $\left.\left.\left.\mathbf{C}_{6} \mathrm{H}_{4} \mathrm{OCH}_{3}\right)_{3} \mathbf{P}\right) \mathbf{A u C l}\right], 1$ was prepared according to the literature procedure. ${ }^{3}$

${ }^{1} \mathrm{H}$ NMR (400 MHz, $\left.\mathrm{CDCl}_{3}\right) \delta 7.45(\mathrm{dd}, J=12.4,8.8 \mathrm{~Hz}, 6 \mathrm{H}), 7.02-6.94(\mathrm{~m}, 6 \mathrm{H}), 3.87$ (s, 9H); ${ }^{31} \mathrm{P}\{\mathrm{H}\}$ NMR $\left(161.96 \mathrm{MHz}, \mathrm{CDCl}_{3}\right): \delta 29.1 \mathrm{ppm}$.

$\left[\left(\left(\mathbf{C}_{6} \mathbf{H}_{4} \mathrm{OCH}_{3}\right)_{3} \mathbf{P}\right) \mathbf{A u C}_{2} \mathbf{P h}\right], 2$ was prepared following to the literature procedure. ${ }^{4}$

${ }^{1} \mathrm{H}$ NMR (400 MHz, $\left.\mathrm{CDCl}_{3}\right) \delta$ 7.56-7.51 (m, 2H), 7.52-7.44 (m, 6H), 7.28-7.19 (m, 3H), 7.00-6.94 $(\mathrm{m}, 6 \mathrm{H}), 3.86(\mathrm{~s}, 9 \mathrm{H}) ;{ }^{31} \mathrm{P}\{\mathrm{H}\} \mathrm{NMR}\left(161.96 \mathrm{MHz}, \mathrm{CDCl}_{3}\right): \delta 39.3 \mathrm{ppm}$.

$\left[\left(\left(\mathbf{C}_{6} \mathbf{H}_{4} \mathbf{O C H}_{3}\right)_{3} \mathbf{P}\right) \mathbf{A u N}_{3}\right], 3$ was prepared by conventional procedures described in the literature. ${ }^{5}$ ${ }^{1} \mathrm{H}$ NMR (400 MHz, $\left.\mathrm{CDCl}_{3}\right) \delta 7.43(\mathrm{dd}, J=12.5,8.6 \mathrm{~Hz}, 6 \mathrm{H}), 6.99(\mathrm{~d}, J=8.3 \mathrm{~Hz}, 6 \mathrm{H}), 3.87$ (s, 9H); ${ }^{31} \mathrm{P}\{\mathrm{H}\}$ NMR $\left(161.96 \mathrm{MHz}, \mathrm{CDCl}_{3}\right): \delta 26.9 \mathrm{ppm}$. FTIR $\left(\mathrm{cm}^{-1}, \mathrm{KBr}\right): v 2062\left(\mathrm{~N}_{3}\right)$.

$\left(\mathrm{Bu}_{4} \mathrm{~N}\right)_{2}\left[\mathrm{~V}_{6} \mathrm{O}_{13}\left\{\left(\mathrm{OCH}_{2}\right)_{3} \mathrm{CCH}_{2} \mathrm{~N}_{3}\right\}_{2}\right], \mathbf{P O M}_{\mathrm{N}}$ was prepared by a protocol described in the literature. ${ }^{6}$ ${ }^{1} \mathrm{H}$ NMR (400 MHz, DMSO-d 6 ): $\delta 4.83$ (s, 12H), 3.69 (s, 4H), 3.13 (m, 16H, TBA), 1.53 (q, 16H, TBA), 1.28 (sextet, 16H, TBA), 0.90 (t, $J=7.2 \mathrm{~Hz}, 24 \mathrm{H}$, TBA). ${ }^{i}$ FTIR ( $\left.\mathrm{cm}^{-1}, \mathrm{KBr}\right): v 2100\left(\mathrm{~N}_{3}\right)$.

$\left(\mathrm{Bu}_{4} \mathrm{~N}\right)_{2}\left[\mathrm{~V}_{6} \mathrm{O}_{13}\left\{\left(\mathrm{OCH}_{2}\right)_{3} \mathrm{CCH}_{2} \mathrm{OCH}_{2} \mathbf{C C H}\right\}_{2}\right], \mathbf{P O M}_{\mathrm{C}}$ was prepared by the literature protocol. ${ }^{7}$

${ }^{1} \mathrm{H}$ NMR (400 MHz, acetonitrile-d $\left.\mathrm{d}_{6}\right): \delta 5.09$ (s, 12H), $4.11(4 \mathrm{H}), 3.43$ (s, 4H), $3.24-3.15$ (m, 16H, TBA), 2.73 (t, $J=2.2 \mathrm{~Hz}, 2 \mathrm{H}), 1.59-1.75$ (m, 16H, TBA), 1.42 (m, $J=7.3 \mathrm{~Hz}, 16 \mathrm{H}, \mathrm{TBA}), 1.01$ (t, $J=7.2 \mathrm{~Hz}, 24 \mathrm{H}, \mathrm{TBA}) .{ }^{\mathrm{i}}{ }^{51} \mathrm{~V}$ NMR $\left(105.25 \mathrm{MHz}, \mathrm{DMSO}-\mathrm{d}_{6}\right): \delta-498 \mathrm{ppm}$. FTIR $\left(\mathrm{cm}^{-1}, \mathrm{KBr}\right): v 2112$ $(\mathrm{C} \equiv \mathrm{C}), 3240-3310$ (terminal $\mathrm{C} \equiv \mathbf{C}-\mathbf{H})$.

\section{$\left(\mathrm{Bu}_{4} \mathrm{~N}\right)_{2}\left[\mathrm{~V}_{6} \mathrm{O}_{13}\left\{\left(\mathrm{OCH}_{2}\right)_{3} \mathrm{CCH}_{2}\left(\mathrm{~N}_{3} \mathrm{C}_{2} \mathrm{C}_{6} \mathrm{H}_{5}\right) \mathrm{AuP}\left(\mathrm{C}_{6} \mathrm{H}_{4} \mathrm{OMe}\right)_{3}\right\}_{2}\right], \mathrm{POM}_{\mathrm{N}}^{\mathrm{Au}}$.}

$25 \mathrm{ml}$ Schlenk flask was degassed, filled with argon and charged with $\mathbf{P O M}_{\mathbf{N}}(7.5 \mathrm{mg}, 0.059 \mathrm{mmol})$, 2 (90 mg, $0.138 \mathrm{mmol}), 15 \mathrm{~mL}$ of a freshly purified degassed DMF, CuI (11 mg, $0.057 \mathrm{mmol})$, and

${ }^{\mathrm{i}} \mathrm{TBA}=$ tetrabutylammonium 
$N, N$-diisopropylethylamine $(17 \mu \mathrm{L})$. The solution was degassed again and stirred at $50^{\circ} \mathrm{C}$ for 72 hours. The resulting solution was passed through a pad of Silica and a pad of Celites, evaporated in vacuo to $c a .3 \mathrm{~mL}$ and diluted with $9 \mathrm{~mL}$ of $\mathrm{Et}_{2} \mathrm{O}$. The precipitate was collected by centrifugation, redissolved in mixture of $1 \mathrm{~mL}$ of DMF and $2 \mathrm{~mL}$ of DCM and then precipitated with $\mathrm{Et}_{2} \mathrm{O}$. The precipitate was washed $\left(3 \times 10 \mathrm{~mL}\right.$ of $\mathrm{Et}_{2} \mathrm{O}, 7 \mathrm{~mL}$ of $\mathrm{DCM} / \mathrm{CH}_{3} \mathrm{CN}(1 / 1)$ and again $10 \mathrm{~mL}$ of $\left.\mathrm{Et}_{2} \mathrm{O}\right)$ and dried in vacuo. The resulting product is a yellow powder which is slightly soluble in DCM and $\mathrm{MeCN}$, and well soluble in DMSO and DMF. Yield: $46 \mathrm{mg}(30 \%)$.

${ }^{1} \mathrm{H}$ NMR (400 MHz, DMSO-d 6 ): $\delta 8.15$ (br m, 4H, $\mathrm{H}^{16}$ ), $7.48\left(\mathrm{dd}, J=12.1,8.3 \mathrm{~Hz}, 12 \mathrm{H}, \mathrm{H}^{6}\right), 7.31$ $\left(\mathrm{m}, 4 \mathrm{H}, \mathrm{H}^{17}\right), 7.23\left(\mathrm{~m}, 2 \mathrm{H}, \mathrm{H}^{18}\right), 7.18\left(\mathrm{~d}, J=7.8 \mathrm{~Hz}, 12 \mathrm{H}, \mathrm{H}^{7}\right), 5.07\left(\mathrm{~s}, 12 \mathrm{H}, \mathrm{H}^{10}\right), 4.43\left(\mathrm{~s}, 4 \mathrm{H}, \mathrm{H}^{12}\right)$, $3.87\left(\mathrm{~s}, 18 \mathrm{H}, \mathrm{H}^{9}\right), 3.16$ (br m, 16H, H $\mathrm{H}^{1}$ ), 1.56 (br m, 16H, H²), 1.29 (br m, 16H, $\mathrm{H}^{3}$ ), 0.91 (br m, 24H, $\left.\mathrm{H}^{4}\right) .{ }^{\mathrm{ii}}$

${ }^{13} \mathrm{C}\left\{{ }^{1} \mathrm{H}\right\}$ NMR (100.6 MHz, DMSO-d 6$): \delta 162.3\left(\mathrm{C}^{8}\right), 135.74\left(\mathrm{~d}, J(\mathrm{C}-\mathrm{P})=10 \mathrm{~Hz}, \mathrm{C}^{6}\right), 133.8\left(\mathrm{C}^{15}\right)$, $128.7\left(\mathrm{C}^{16}\right), 127.1\left(\mathrm{C}^{18}\right), 126.1\left(\mathrm{C}^{17}\right), 121.1\left(\mathrm{~d}, J(\mathrm{C}-\mathrm{P})=61.4 \mathrm{~Hz}, \mathrm{C}^{5}\right), 115.2\left(\mathrm{~d}, J(\mathrm{C}-\mathrm{P})=7 \mathrm{~Hz}, \mathrm{C}^{7}\right)$, $84.9\left(\mathrm{C}^{10}\right), 57.9\left(\mathrm{C}^{1}\right), 56.0\left(\mathrm{C}^{9}\right), 53.7\left(\mathrm{C}^{12}\right), 23.5\left(\mathrm{C}^{2}\right), 19.6\left(\mathrm{C}^{3}\right), 14.0\left(\mathrm{C}^{4}\right)$. Quaternary $\mathrm{C}^{11}, \mathrm{C}^{13}$ and $\mathrm{C}^{14}$ are not observed due to low intensity. ${ }^{\text {ii }}$

${ }^{31} \mathrm{P}\left\{{ }^{1} \mathrm{H}\right\}$ NMR (161.96 MHz, DMSO-d 6 ): $\delta 39.6 \mathrm{ppm}$.

${ }^{51} \mathrm{~V}\left\{{ }^{1} \mathrm{H}\right\}$ NMR (105.25 MHz, DMSO-d 6$): \delta-493 \mathrm{ppm}$.

$\mathrm{ESI}^{-} \mathrm{MS} \mathrm{m} / \mathrm{z}:[\mathrm{M}]^{2-}$ found 1064.9777, calcd. 1064.9834; $[\mathrm{M}+\mathrm{O}]^{2-}$ found 1072.9803, calcd. 1072.9808, where $\mathrm{M}=\left[\mathrm{C}_{68} \mathrm{H}_{68} \mathrm{Au}_{2} \mathrm{~N}_{6} \mathrm{O}_{25} \mathrm{P}_{2} \mathrm{~V}_{6}\right]$.

FTIR spectrum shows no signal at $2100 \mathrm{~cm}^{-1}\left(\mathrm{~N}_{3}\right.$ group of $\left.\mathbf{P O} \mathbf{M}_{\mathbf{N}}\right)$, see Fig. S6.

\section{$\left(\mathrm{Bu}_{4} \mathrm{~N}\right)_{2}\left[\mathrm{~V}_{6} \mathrm{O}_{13}\left\{\left(\mathrm{OCH}_{2}\right)_{3} \mathrm{CCH}_{2} \mathrm{OCH}_{2}\left(\mathrm{C}_{2} \mathrm{~N}_{3} \mathrm{H}\right) \mathrm{AuP}\left(\mathrm{C}_{6} \mathrm{H}_{4} \mathrm{OMe}\right)_{3}\right\}_{2}\right], \mathrm{POM}_{\mathrm{C}}^{\mathrm{Au}}$.}

25 mL Schlenk flask was degassed, filled with argon and then charged with $\mathbf{P O M}_{\mathbf{C}}(61.4 \mathrm{mg}, 0.046$ mmol), 3 (60.4 mg, $0.102 \mathrm{mmol}), 5 \mathrm{~mL}$ of freshly purified degassed DMF, and DIPEA (10 $\mu \mathrm{L})$. The solution was degassed and stirred at $35^{\circ} \mathrm{C}$ during 50 hours. The resulting solution passed through a pad of neutral $\mathrm{Al}_{2} \mathrm{O}_{3}$ and a pad of Celites, evaporated under vacuum to $c a .3 \mathrm{~mL}$ and diluted by $9 \mathrm{~mL}$ of $\mathrm{Et}_{2} \mathrm{O}$. The resulting precipitate was collected by centrifugation, re-dissolved in mixture of $1 \mathrm{~mL}$ of $\mathrm{DMF}$ and $2 \mathrm{~mL}$ of DCM, and again was precipitated by $\mathrm{Et}_{2} \mathrm{O}$. The precipitate was washed $(3 \times 10 \mathrm{~mL}$ of $\mathrm{Et}_{2} \mathrm{O} / \mathrm{DCM}(5 / 1), 10 \mathrm{~mL}$ of $\left.\mathrm{Et}_{2} \mathrm{O}\right)$ and dried in vacuo. The resulting product is a yellow powder which is slightly soluble in DCM and MeCN, and well soluble in DMSO and DMF, giving brown solutions. Yield: $69 \mathrm{mg}(60 \%)$.

${ }^{1} \mathrm{H}$ NMR (400 MHz, DMSO- $\left.d_{6}\right): \delta 14.13\left(\mathrm{~s}, 2 \mathrm{H}, \mathrm{H}^{16}\right.$ ), 7.48 (dd, $J=12.5,8.4 \mathrm{~Hz}, 12 \mathrm{H}, \mathrm{H}^{6}$ ), 7.16 (dd, $\left.J=8.5,1.5 \mathrm{~Hz}, 12 \mathrm{H}, \mathrm{H}^{7}\right), 4.85\left(\mathrm{~s}, 12 \mathrm{H}, \mathrm{H}^{10}\right), 4.50\left(\mathrm{~s}, 4 \mathrm{H}, \mathrm{H}^{15}\right), 3.86\left(\mathrm{~s}, 18 \mathrm{H}, \mathrm{H}^{9}\right), 3.28\left(\mathrm{~s}, 4 \mathrm{H}, \mathrm{H}^{12}\right)$, $3.17\left(\mathrm{~m}, 16 \mathrm{H}, \mathrm{H}^{1}\right), 1.58\left(\mathrm{~m}, 16 \mathrm{H}, \mathrm{H}^{2}\right), 1.32\left(\mathrm{~m}, 16 \mathrm{H}, \mathrm{H}^{3}\right), 0.93\left(\mathrm{t}, J=7.1 \mathrm{~Hz}, 24 \mathrm{H}, \mathrm{H}^{4}\right)$. ${ }^{\mathrm{ii}}$

\footnotetext{
ii Assignment of signals in ${ }^{1} \mathrm{H}$ and ${ }^{13} \mathrm{C}$ NMR spectra is given in accordance with numeration shown in Scheme S1.
} 
${ }^{13} \mathrm{C}\{\mathrm{H}\}$ NMR $\left(100.6 \mathrm{MHz}, \mathrm{DMSO}-d_{6}\right): \delta 163.9\left(\mathrm{C}^{14}\right), 162.3\left(\mathrm{C}^{8}\right), 148.7\left(\mathrm{C}^{13}\right), 135.8(\mathrm{~d}, J(\mathrm{C}-\mathrm{P})=15$ $\left.\mathrm{Hz}, \mathrm{C}^{6}\right), 121.5\left(\mathrm{~d}, J(\mathrm{C}-\mathrm{P})=61.4 \mathrm{~Hz}, \mathrm{C}^{5}\right), 115.8\left(\mathrm{~d}, J(\mathrm{C}-\mathrm{P})=12 \mathrm{~Hz}, \mathrm{C}^{7}\right), 84.0\left(\mathrm{C}^{10}\right), 70.1\left(\mathrm{C}^{12}\right), 66.9$ $\left(\mathrm{C}^{15}\right), 58.0\left(\mathrm{C}^{1}\right), 56.1\left(\mathrm{C}^{9}\right), 23.6\left(\mathrm{C}^{2}\right), 19.7\left(\mathrm{C}^{3}\right), 14.0\left(\mathrm{C}^{4}\right)$. Quaternary $\mathrm{C}^{11}$ is not observed due to low intensity. ${ }^{\text {ii }}$

${ }^{31} \mathrm{P}\left\{{ }^{1} \mathrm{H}\right\}$ NMR (161.96 MHz, DMSO-d 6$): \delta 39.8 \mathrm{ppm}$.

${ }^{51} \mathrm{~V}\left\{{ }^{1} \mathrm{H}\right\}$ NMR (105.25 MHz, DMSO-d 6$): \delta-493 \mathrm{ppm}$.

Anal. Calcd. for $\mathrm{C}_{90} \mathrm{H}_{136} \mathrm{Au}_{2} \mathrm{~N}_{8} \mathrm{O}_{27} \mathrm{P}_{2} \mathrm{~V}_{6}$ : C, 42.83\%; H, 5.43\%; N, 4.44\%. Found: $\mathrm{C}, 42.19 \% ; \mathrm{H}$, $5.39 \% ; \mathrm{N}, 4.27 \%$.

$\mathrm{ESI}^{-} \mathrm{MS} \mathrm{m} / z:[\mathrm{M}+\mathrm{H}]^{-}$found 2038.9698, calcd. 2038.9336; $[\mathrm{M}+\mathrm{Na}]^{-}$found 2060.9598, calcd. 2060.9680; $\left[\mathrm{M}+\mathrm{NBu}_{4}\right]^{-}$found 2280.2638, calcd. 2280.2558; [M] $]^{2-}$ found 1018.9611, calcd. 1018.9637, where $\mathrm{M}=\left[\mathrm{C}_{58} \mathrm{H}_{64} \mathrm{Au}_{2} \mathrm{~N}_{6} \mathrm{O}_{27} \mathrm{P}_{2} \mathrm{~V}_{6}\right]$.

FTIR spectrum shows no peaks at $2062 \mathrm{~cm}^{-1}\left(\mathrm{~N}_{3}\right.$ group of 3 ), at $2112 \mathrm{~cm}^{-1}$ (terminal $\mathrm{C} \equiv \mathrm{C}$ groups of $\mathbf{P O M}_{\mathbf{C}}$ ), and in the region of $3240-3310 \mathrm{~cm}^{-1}$ (terminal $\mathrm{C}_{2}-\mathrm{H}$ groups of $\mathbf{P O M}$ ), see Fig. S7.
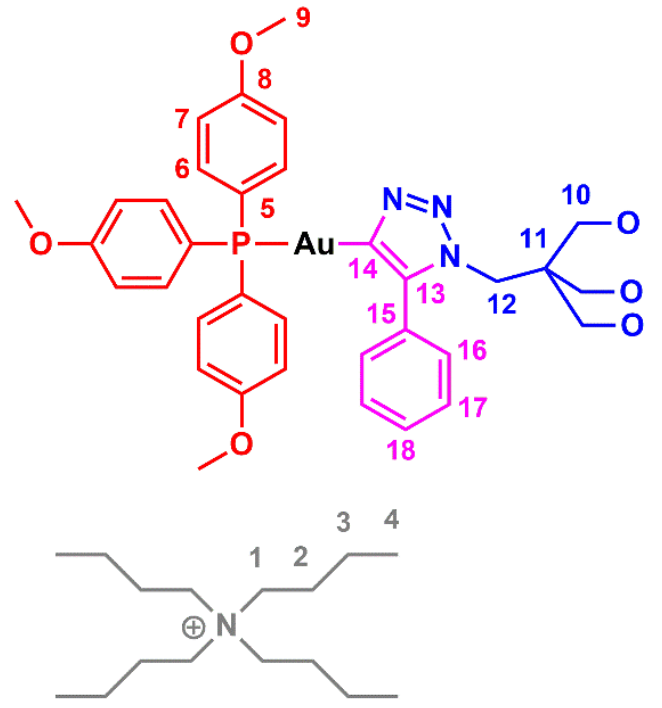
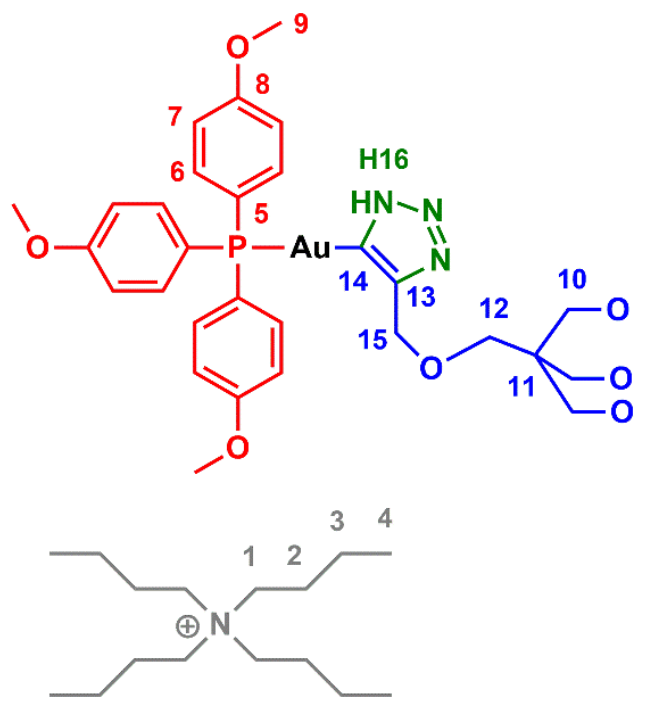

Scheme S1. Atom numeration for assignment of the signals in ${ }^{1} \mathrm{H}$ and ${ }^{13} \mathrm{C}$ NMR spectra of $\mathbf{P O} \mathbf{M}_{\mathbf{N}}^{\mathrm{Au}}$ (left) and $\mathbf{P O M}_{\mathbf{C}}^{\mathrm{Au}}$ (right). The half of symmetric organic part of the molecules is depicted. 


\section{DFT calculations}

Density functional theory (DFT) calculations were performed for isolated molecules with CAMB3LYP long-range-corrected hybrid functional ${ }^{8}$ using SDD basis set with the MWB60 effective core potential ${ }^{9}$ for $\mathrm{Au}$ atoms and $6-311 \mathrm{G}^{*}$ basis set for all other atoms. Full geometry optimizations were carried out for the ground-state structures of $\mathbf{P O M}_{\mathbf{C}}, \mathbf{P O M}_{\mathbf{N}}, \mathbf{P O M}_{\mathbf{N}}^{\mathrm{Au}}, \mathbf{P O M}_{\mathbf{C}}^{\mathrm{Au}}$, and two $\mathrm{Au}(\mathrm{I})$ precursor complexes. In the case of $\mathbf{P O M}_{\mathbf{N}}^{\mathbf{A u}}$ and $\mathbf{P O M}_{\mathbf{C}}^{\mathbf{A u}}$ hybrids DFT calculations were also performed for reduced species, which were obtained by addition of up to four electrons. Natural population analysis (NPA) ${ }^{10}$ was performed for the resulting structures to study the redistribution of electron density upon formation of hybrid species and their reduced derivatives. All calculations were carried out using Gaussian 16. ${ }^{11}$ Population analysis was performed by NBO $3.1^{12}$ as implemented in Gaussian 16. 


\section{$\operatorname{POM}_{N}^{A u}$}
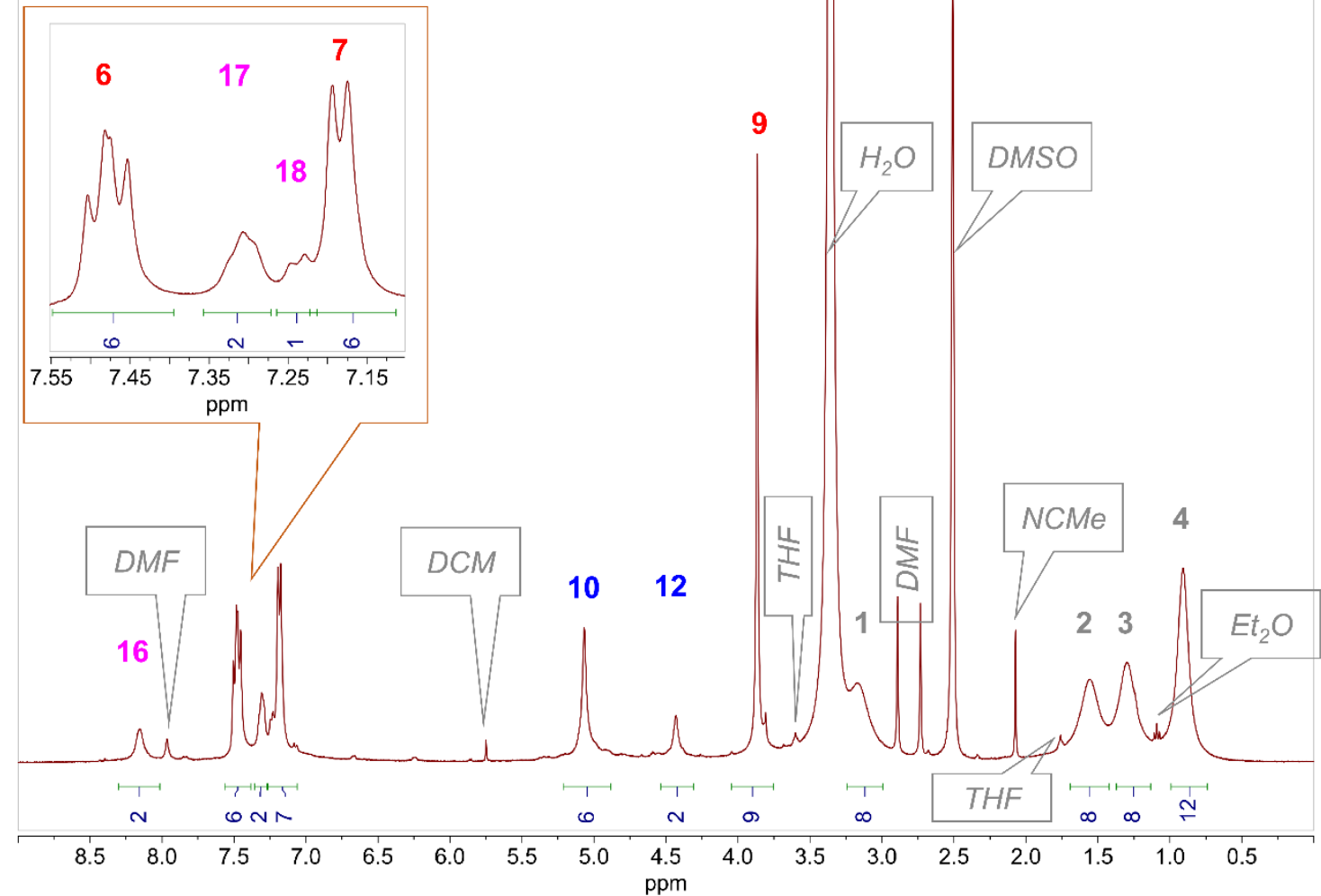

\section{$\mathbf{P O M}_{\mathrm{C}}^{\mathrm{Au}}$}

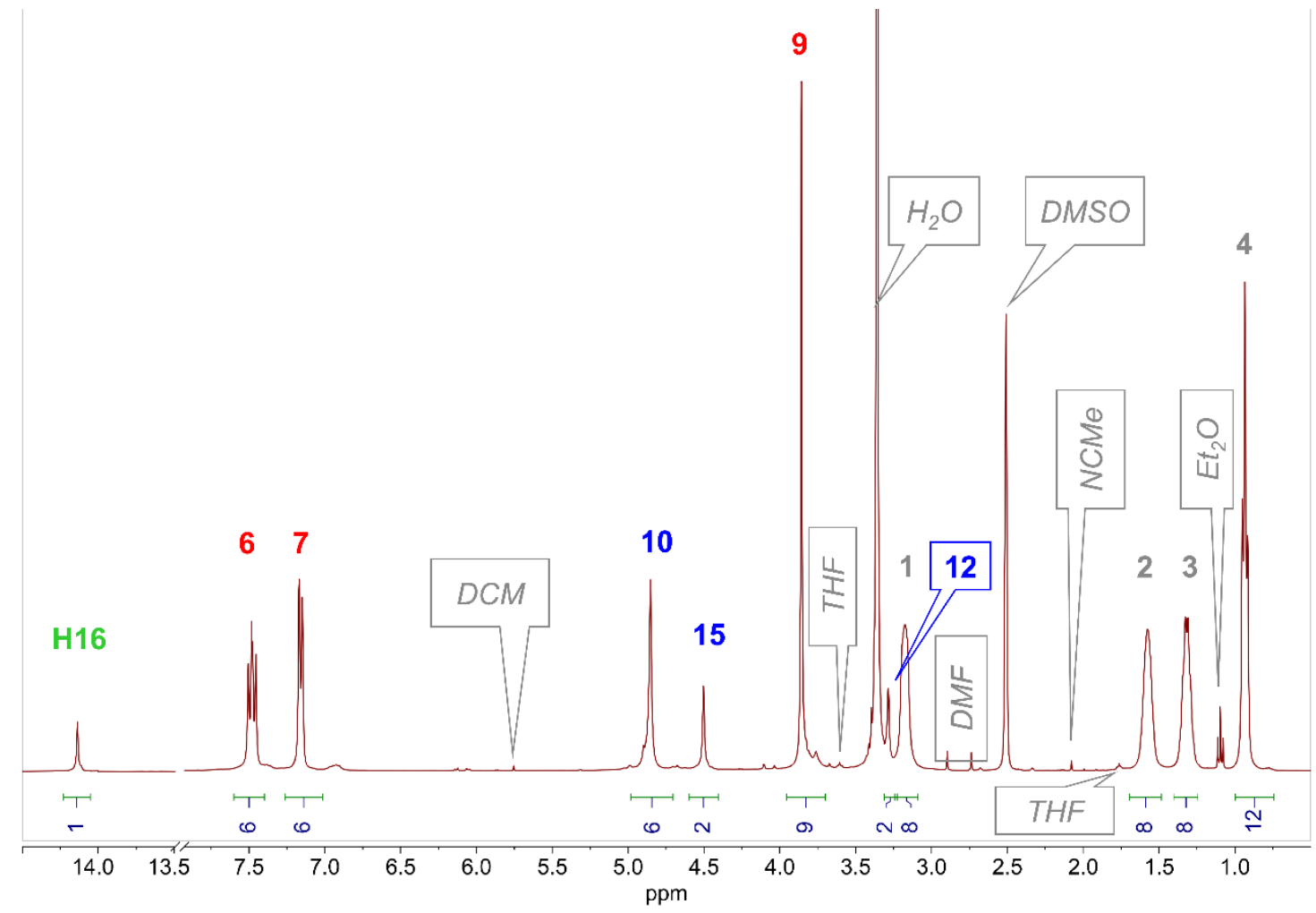

Figure S1. ${ }^{1} \mathrm{H}$ NMR spectra of $\mathbf{P O M}_{\mathbf{N}}^{\text {Au }}$ (top) and $\mathbf{P O} \mathbf{M}_{\mathbf{C}}^{\mathbf{A u}}$ (bottom), DMSO-d 6 , r.t. Integral intensities are given for half of symmetric organic part of the molecule. ${ }^{\text {ii }}$ 

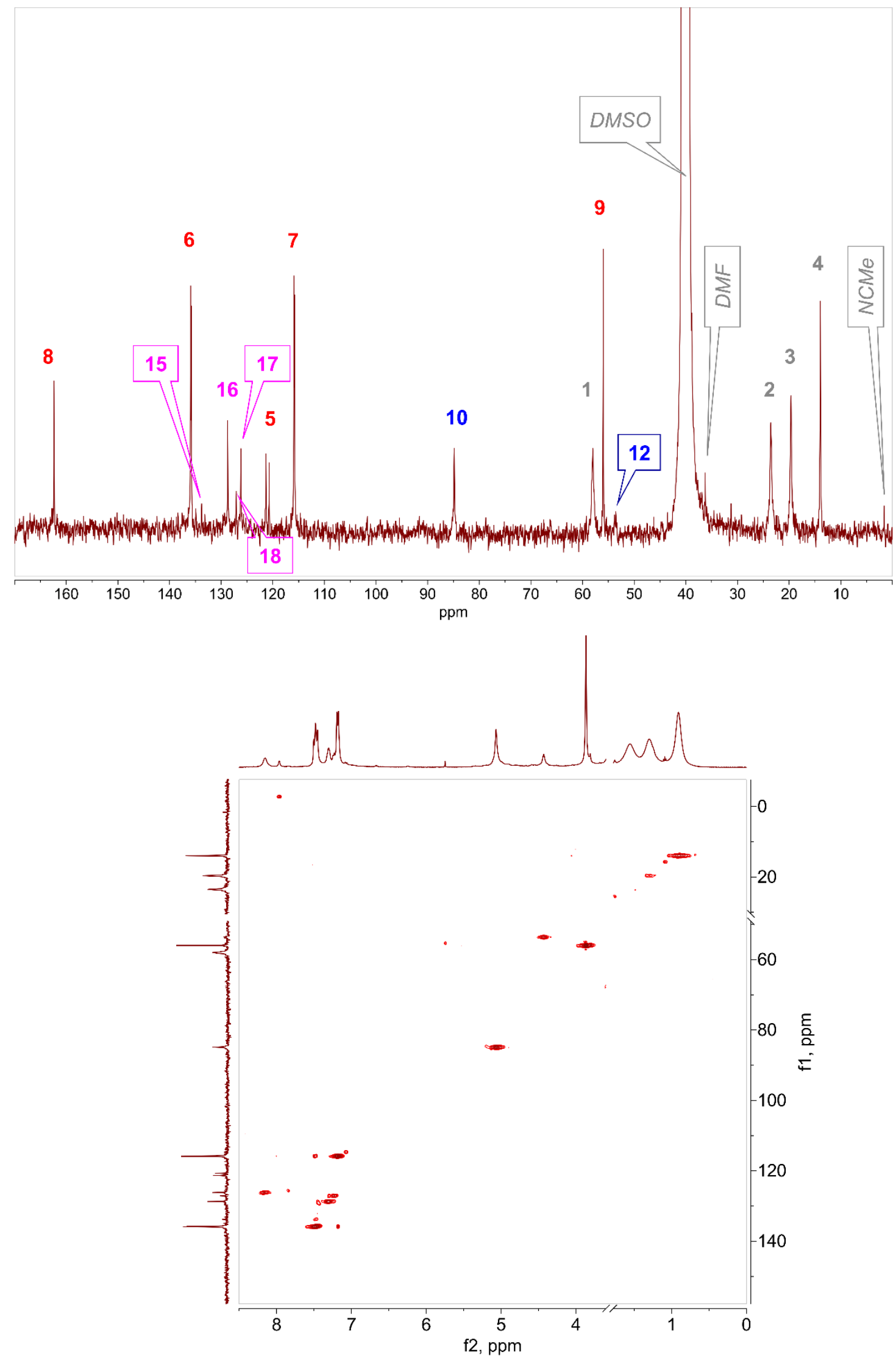

Figure S2. ${ }^{13} \mathrm{C}\left\{{ }^{1} \mathrm{H}\right\}$ (top) and HSQC (bottom) NMR spectra of $\mathbf{P O M}_{\mathbf{N}}^{\text {Au }}$, DMSO-d 6 , r.t. ${ }^{\text {ii }}$ 

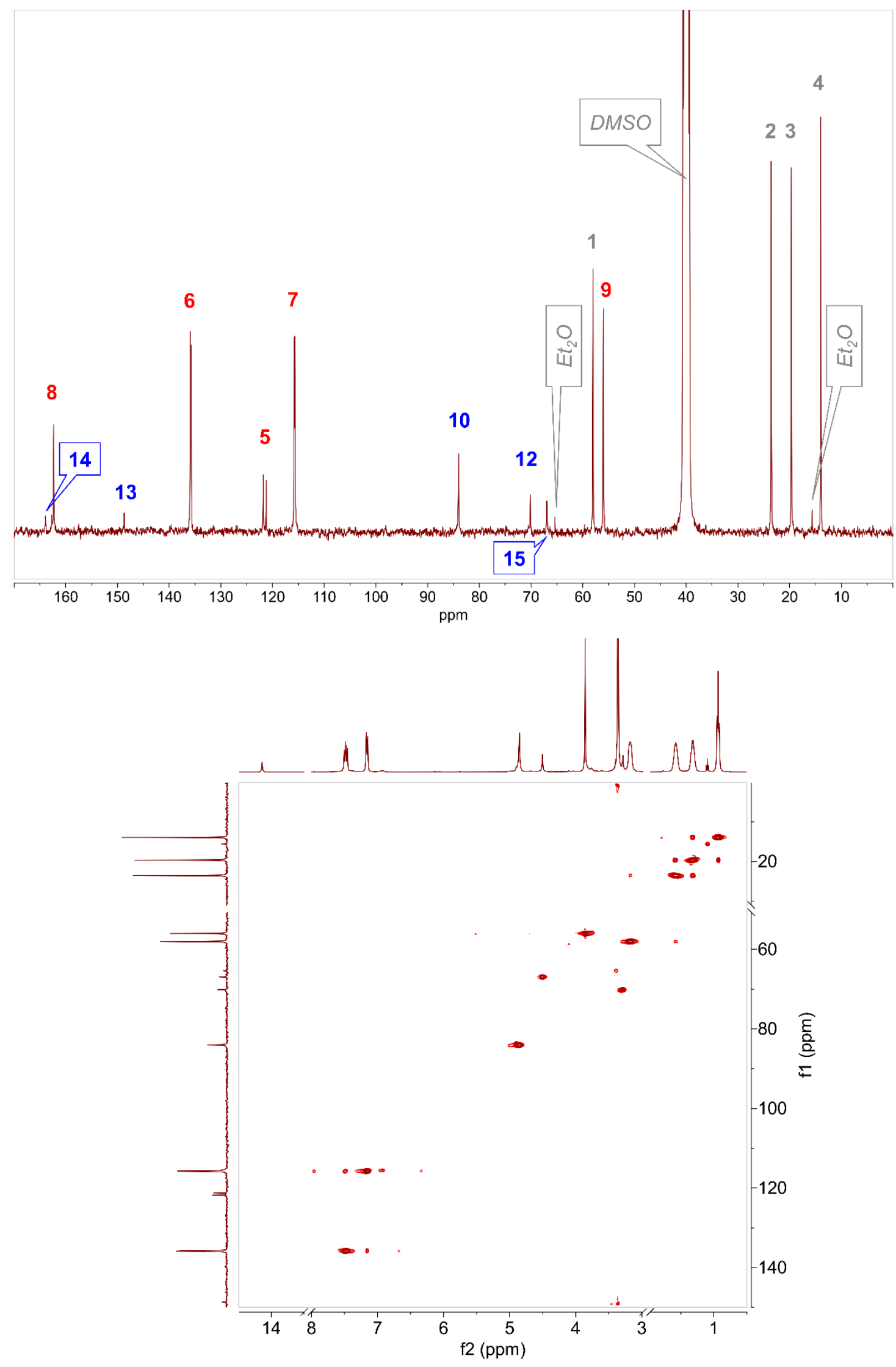

Figure S3. ${ }^{13} \mathrm{C}\left\{{ }^{1} \mathrm{H}\right\}$ (top) and HSQC (bottom) NMR spectra of $\mathbf{P O M}_{\mathbf{C}}^{\text {Au }}$, DMSO-d 6 , r.t. ${ }^{\text {ii }}$ 

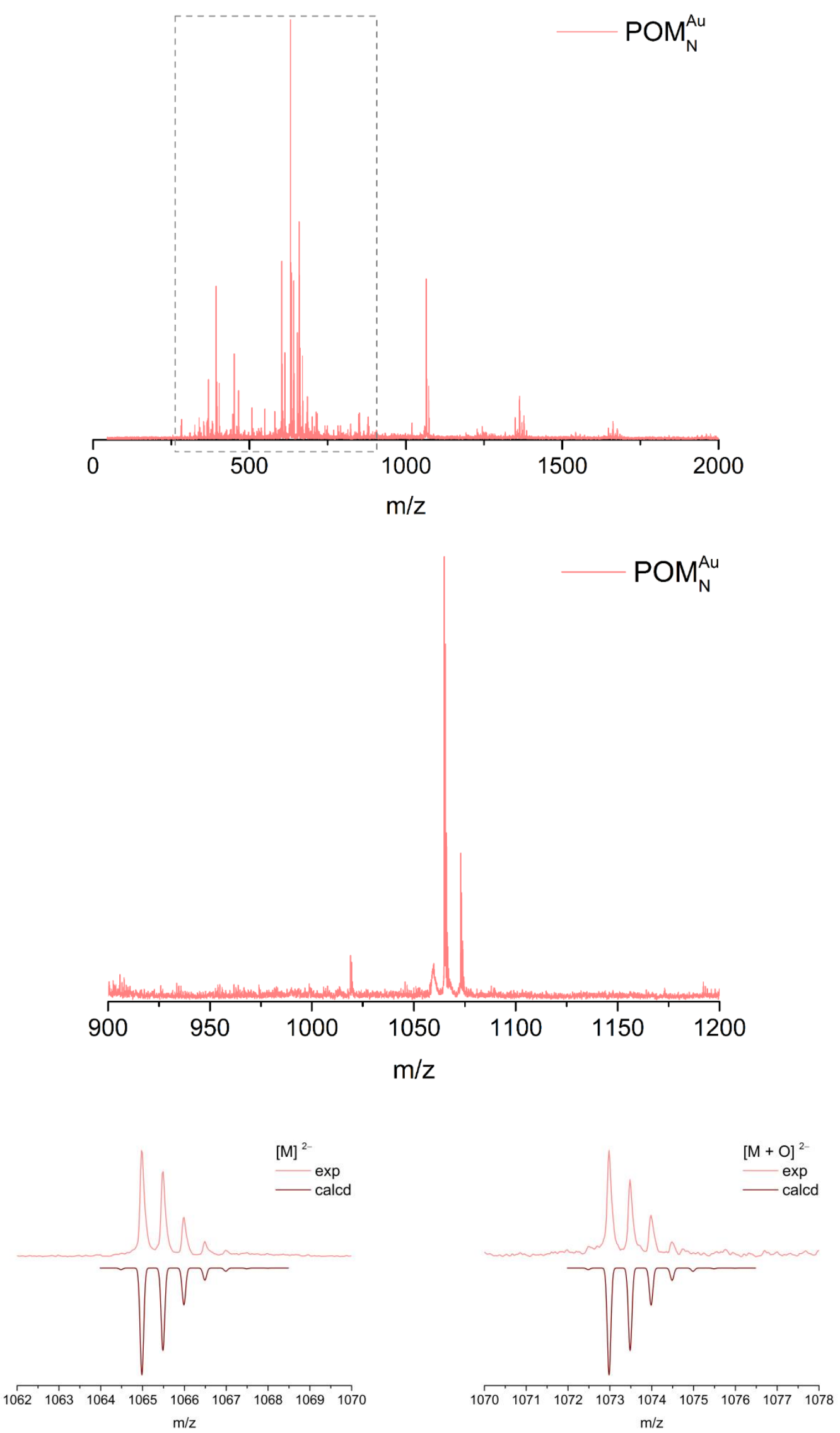

Figure S4. ESI-MS of $\mathbf{P O M}_{\mathbf{N}}^{\text {Au }}$ : experimental spectrum and simulated isotopic patterns for the dominating signals. Region of decomposition fragments is highlighted by dashed frame. $[\mathrm{M}]^{2-}=$ $\left[\mathrm{V}_{6} \mathrm{O}_{13}\left\{\left(\mathrm{OCH}_{2}\right)_{3} \mathrm{CCH}_{2}\left(\mathrm{~N}_{3} \mathrm{C}_{2} \mathrm{C}_{6} \mathrm{H}_{5}\right) \mathrm{AuP}\left(\mathrm{C}_{6} \mathrm{H}_{4} \mathrm{OMe}\right)_{3}\right\}_{2}\right]^{2-}$. 

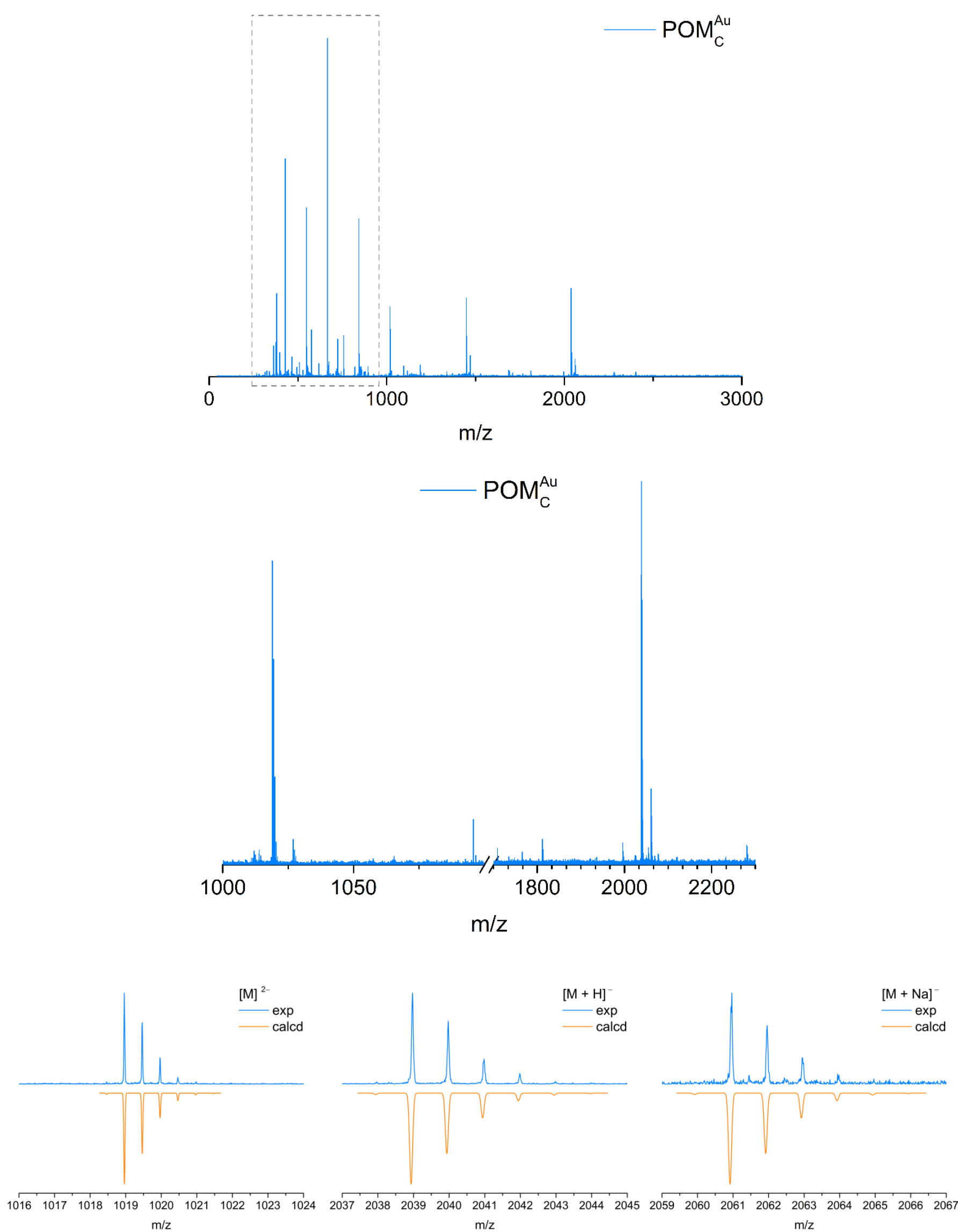

Figure S5. ESI-MS of $\mathbf{P O M}_{\mathbf{C}}^{\mathbf{A u}}$ : experimental spectrum and simulated isotopic patterns for the dominating signals. Region of decomposition fragments is highlighted by dashed frame. $[\mathrm{M}]^{2-}=$ $\left[\mathrm{V}_{6} \mathrm{O}_{13}\left\{\left(\mathrm{OCH}_{2}\right)_{3} \mathrm{CCH}_{2} \mathrm{OCH}_{2}\left(\mathrm{C}_{2} \mathrm{~N}_{3} \mathrm{H}\right) \mathrm{AuP}\left(\mathrm{C}_{6} \mathrm{H}_{4} \mathrm{OMe}\right)_{3}\right\}_{2}\right]^{2-}$. 


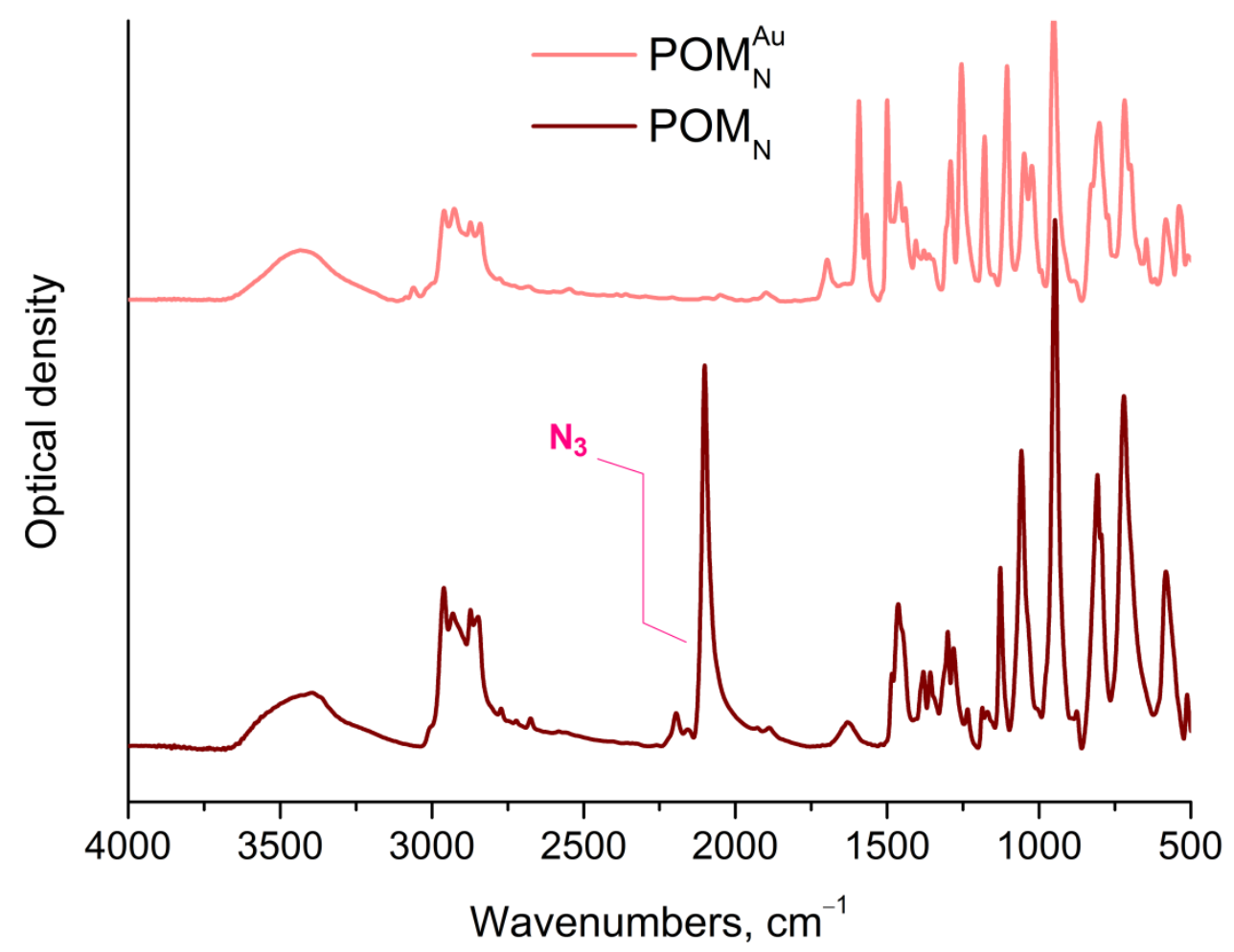

Figure S6. FTIR spectra of $\left(n-\mathrm{Bu}_{4} \mathrm{~N}\right)_{2}\left[\mathrm{~V}_{6} \mathrm{O}_{13}\left\{\left(\mathrm{OCH}_{2}\right)_{3} \mathrm{CCH}_{2}\left(\mathrm{~N}_{3} \mathrm{C}_{2} \mathrm{C}_{6} \mathrm{H}_{5}\right) \mathrm{AuP}\left(\mathrm{C}_{6} \mathrm{H}_{4} \mathrm{OMe}\right)_{3}\right\}_{2}\right]$ $\left(\mathbf{P O M}_{\mathbf{N}}^{\mathrm{Au}}\right)$ and $\mathbf{P O M}_{\mathbf{N}}$ in the fingerprint region, $\mathrm{KBr}$.

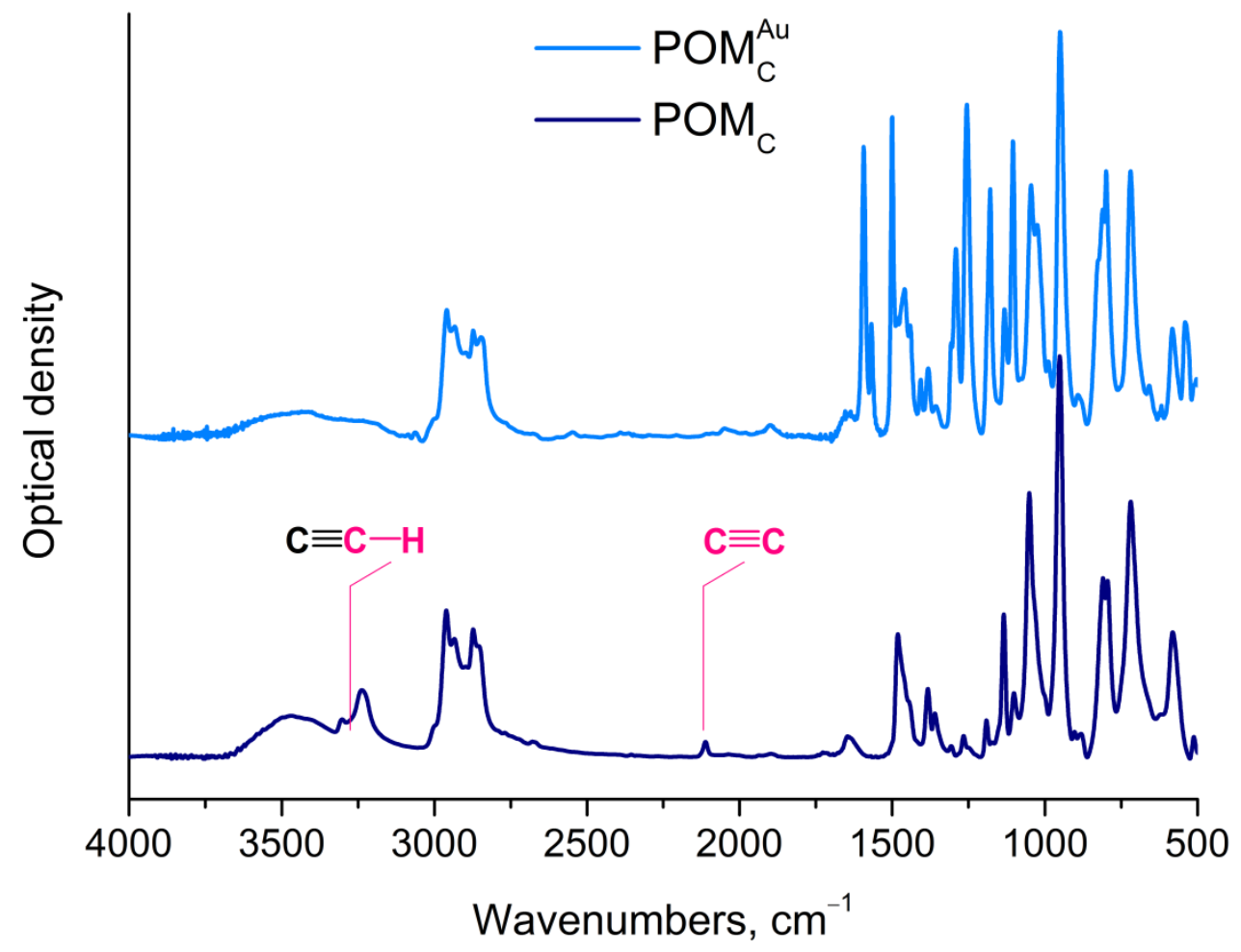

Figure S7. FTIR spectra of $\left(n-\mathrm{Bu}_{4} \mathrm{~N}\right)_{2}\left[\mathrm{~V}_{6} \mathrm{O}_{13}\left\{\left(\mathrm{OCH}_{2}\right)_{3} \mathrm{CCH}_{2} \mathrm{OCH}_{2}\left(\mathrm{C}_{2} \mathrm{~N}_{3} \mathrm{H}\right) \mathrm{AuP}\left(\mathrm{C}_{6} \mathrm{H}_{4} \mathrm{OMe}\right)_{3}\right\}_{2}\right]$ $\left(\mathbf{P O M}_{\mathbf{C}}^{\mathbf{A u}}\right)$ and $\mathbf{P O M} \mathbf{M}_{\mathbf{C}}$ in the fingerprint region, $\mathrm{KBr}$. 


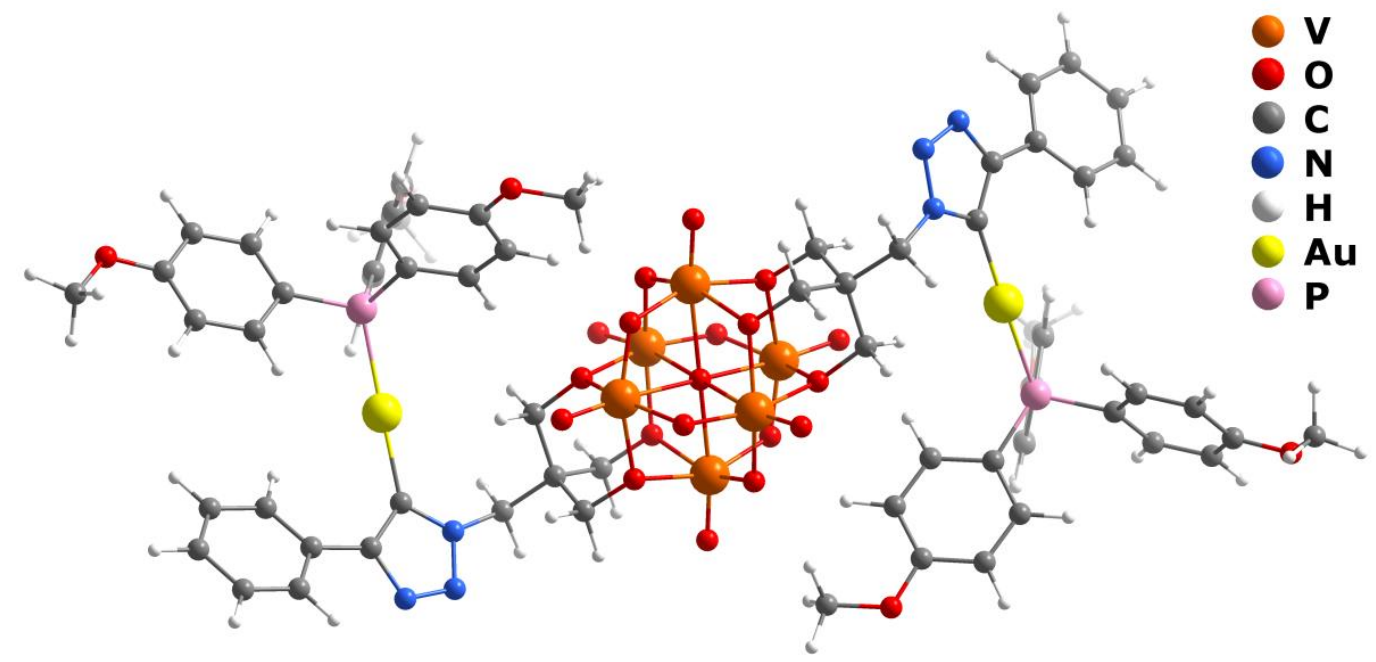

Figure S8. Minimum energy structure of hybrid $\mathbf{P O M}_{\mathbf{N}}^{\mathrm{Au}}$ (CAM-B3LYP DFT calculation).
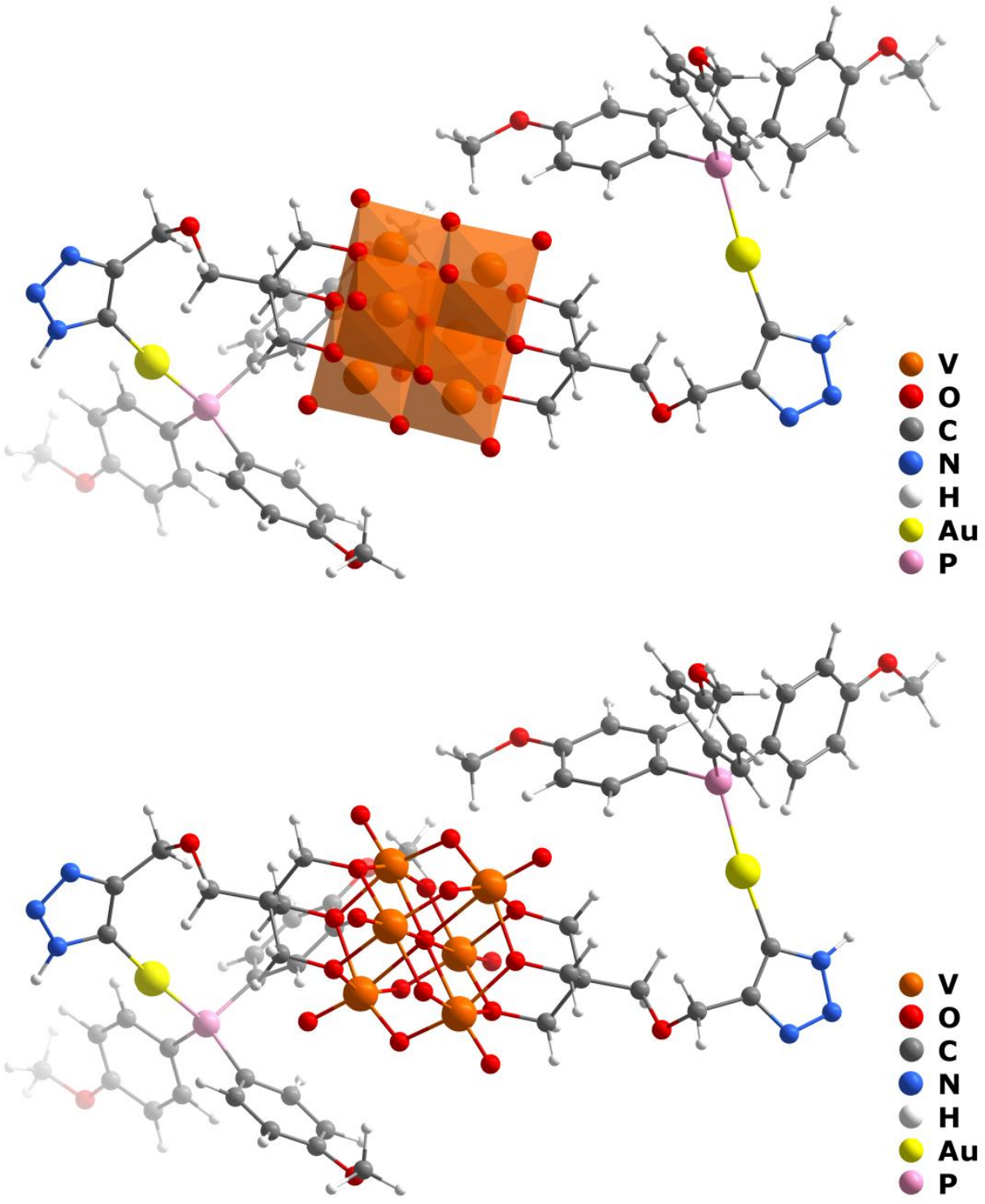

Figure S9. Minimum energy structure of hybrid $\mathbf{P O M}_{\mathbf{C}}^{\mathrm{Au}}$ (two modes with and without $\left\{\mathrm{VO}_{6}\right\}$ octahedral filling, CAM-B3LYP DFT calculation). 
Table S1. Calculated $\left(\mathbf{P O M}_{\mathbf{N}}, \mathbf{P O M}_{\mathrm{C}}, \mathbf{P O M}_{\mathbf{N}}^{\mathrm{Au}}, \mathbf{P O M}_{\mathrm{C}}^{\mathrm{Au}}\right)$ and experimental $\left(\mathbf{P O M}_{\mathbf{N}}, \mathbf{P O} \mathbf{M}_{\mathbf{C}}\right)$ average bond lengths $(\AA) \mathrm{V}-\mathrm{O}$ and $\mathrm{C}-\mathrm{O}^{[-\mathrm{V}]}$ in the hexavanadate core.

\begin{tabular}{|c|c|c|c|c|c|}
\hline \multirow{2}{*}{ Compound } & \multicolumn{4}{|c|}{ V-O } & \multirow{2}{*}{$\mathrm{C}-\mathrm{O}^{[-\mathrm{V}}$} \\
\hline & $\kappa^{1}, \mu^{6}-O$ & $\mu_{2}-\mathrm{O}$ & $t-O$ & $\mu_{3}-\mathrm{O}[-\mathrm{C}]$ & \\
\hline $\mathbf{P O M}_{\mathbf{N}}{ }^{13}$ & 2.239 & 1.830 & 1.607 & 2.020 & 1.433 \\
\hline $\mathrm{POM}_{\mathrm{N}}^{\text {calcd }}$ & 2.249 & 1.794 & 1.573 & 2.032 & 1.403 \\
\hline $\operatorname{POM}_{\mathrm{N}}^{\mathrm{Au}}$ & 2.248 & 1.798 & 1.572 & 2.027 & 1.408 \\
\hline $\mathrm{POM}_{\mathrm{C}}{ }^{7}$ & 2.241 & 1.827 & 1.606 & 2.015 & 1.431 \\
\hline $\mathrm{POM}_{\mathrm{C}}^{\text {calcd }}$ & 2.249 & 1.794 & 1.573 & 2.032 & 1.403 \\
\hline $\operatorname{POM}_{C}^{A u}$ & 2.247 & 1.799 & 1.573 & 2.023 & 1.413 \\
\hline
\end{tabular}




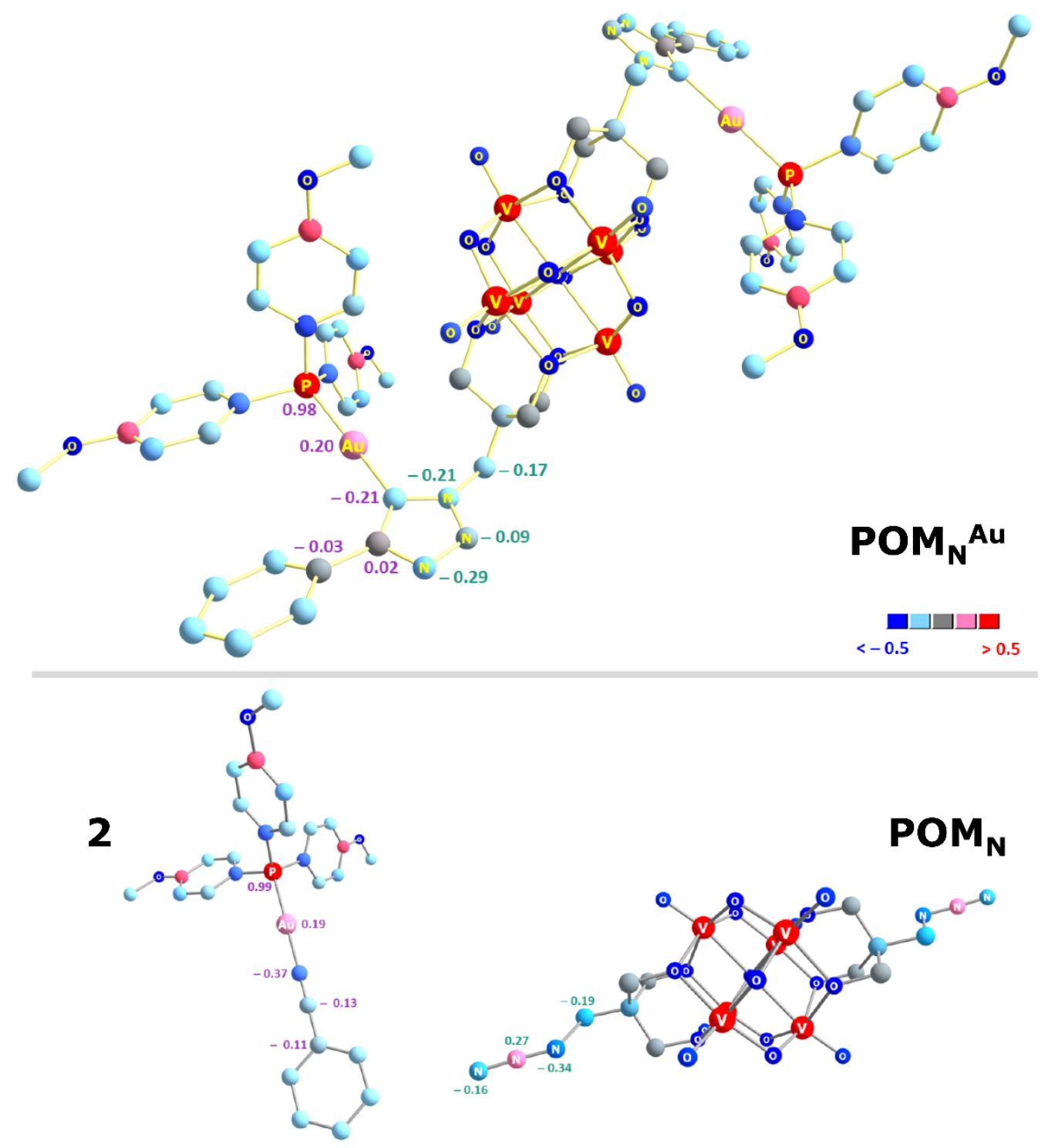

Figure S10. Charge redistribution in the junction region upon formation of $\mathbf{P O M}_{\mathbf{N}}^{\mathrm{Au}}$ hybrid. $\mathbf{P O} \mathbf{M}_{\mathbf{N}}$ and $\mathrm{Au}(\mathrm{I})$ precursor complex 2 are shown as reference. Numbers in the figure are the calculated effective charges obtained from NPA. Values are shown only for those atoms, for which the charge changes by more than 0.01 upon formation of the hybrid. Atom colors indicate positive/negative charges (see legend). 

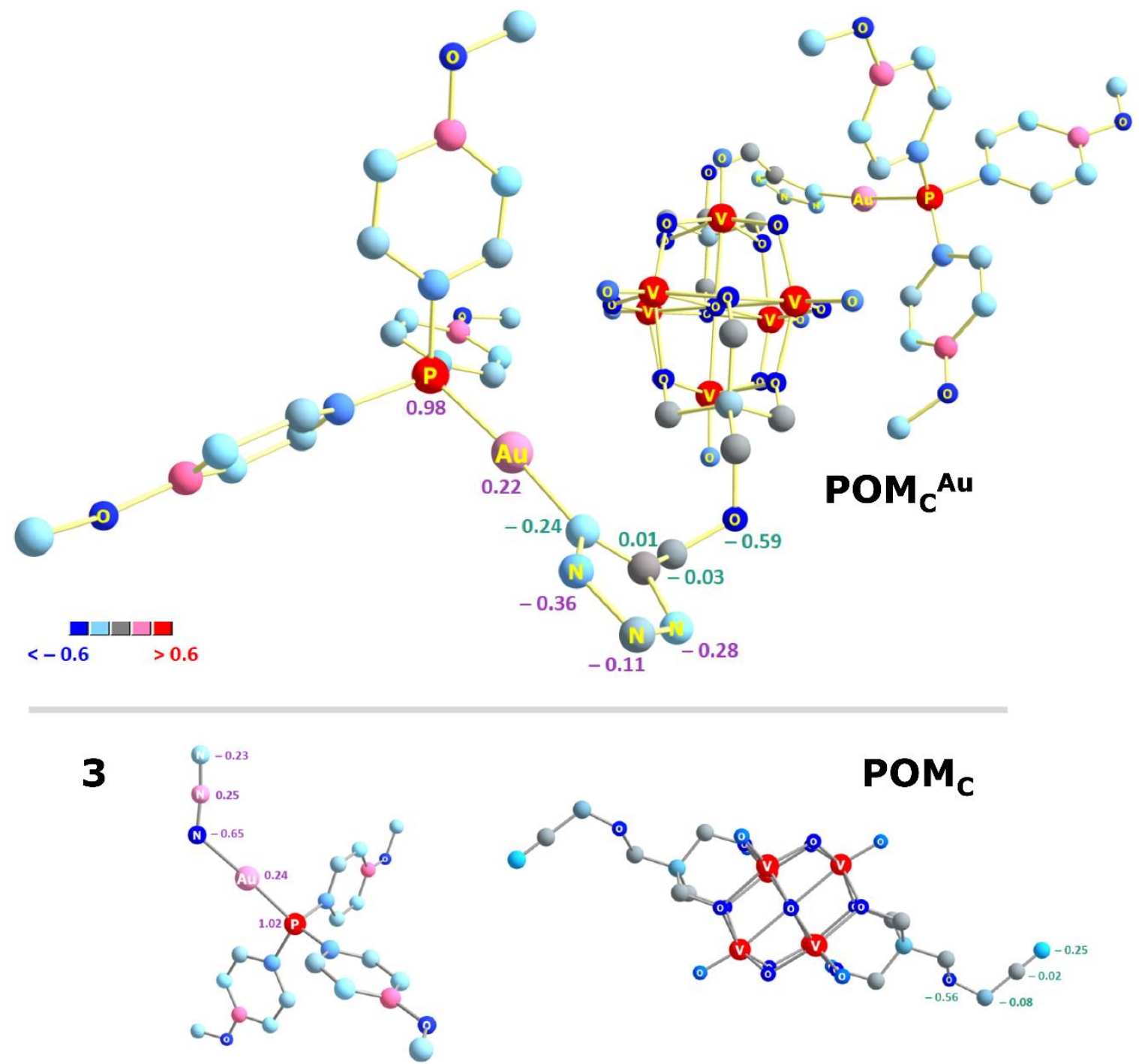

Figure S11. Charge redistribution in the junction region upon formation of $\mathbf{P O M}_{\mathbf{C}}^{\mathrm{Au}}$ hybrid. $\mathbf{P O} \mathbf{M}_{\mathbf{C}}$ and $\mathrm{Au}(\mathrm{I})$ precursor complex $\mathbf{3}$ are shown as reference. Numbers in the figure are the calculated effective charges obtained from NPA. Values are shown only for those atoms, for which the charge changes by more than 0.01 upon formation of the hybrid. Atom colors indicate positive/negative charges (see legend). 

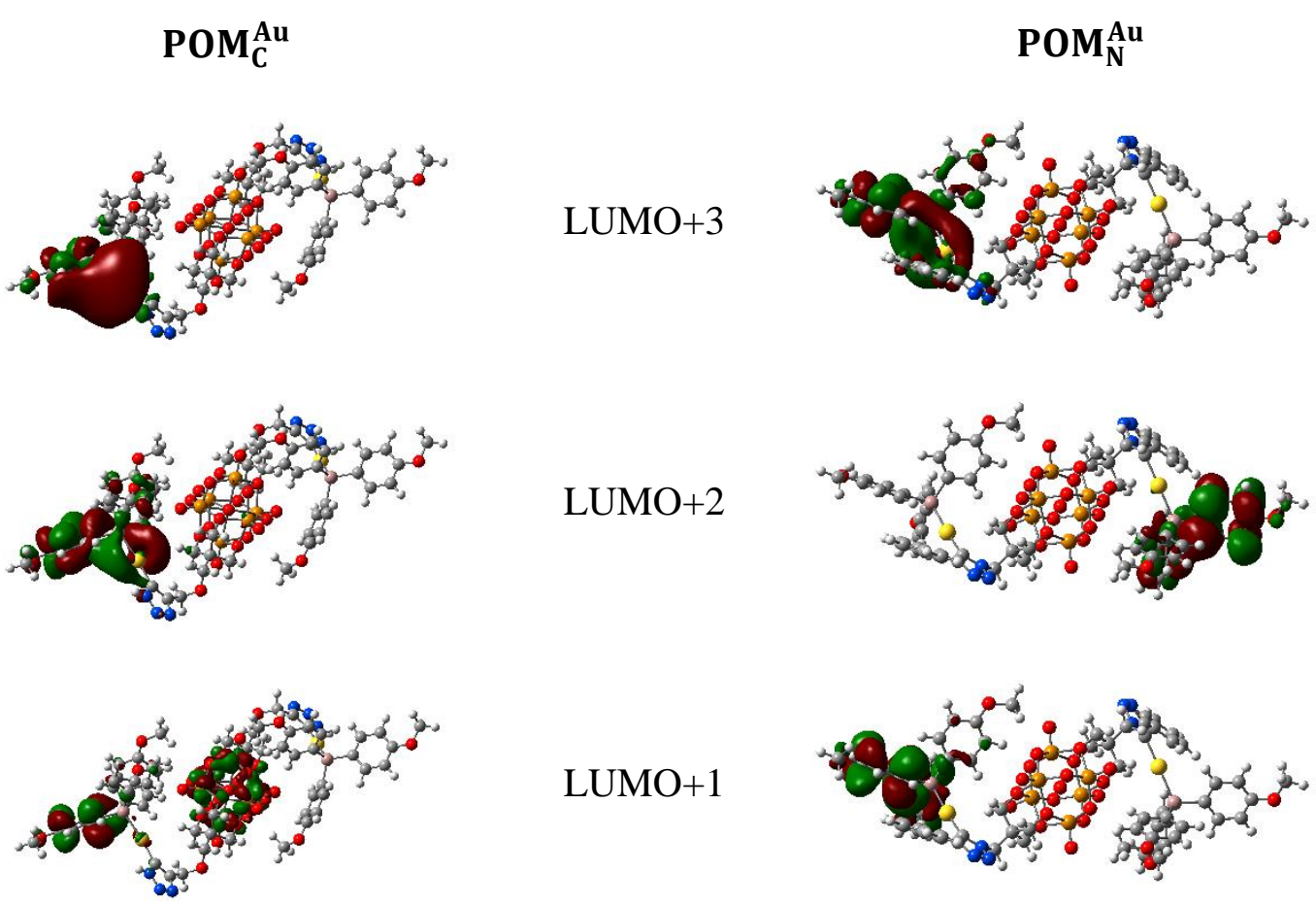

LUMO+1
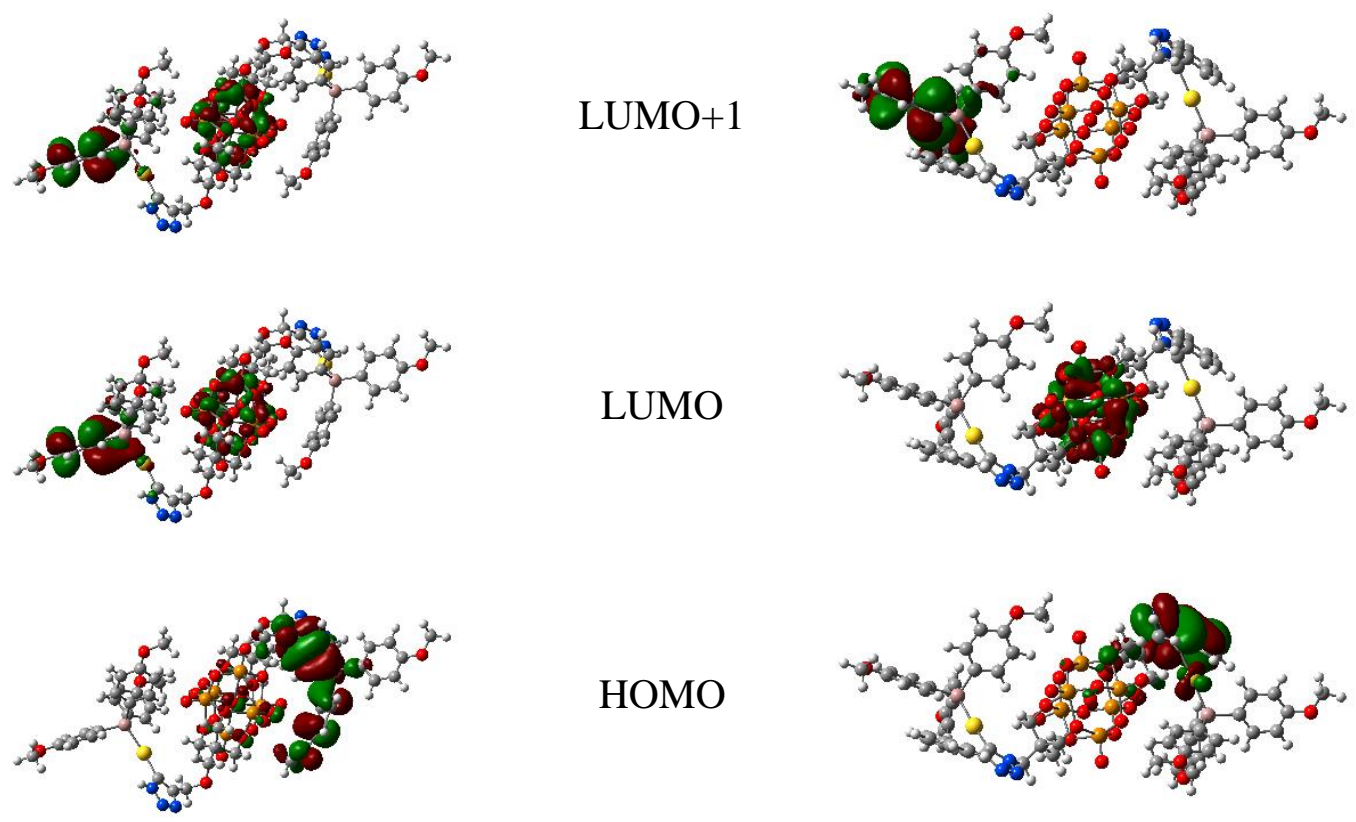

LUMO

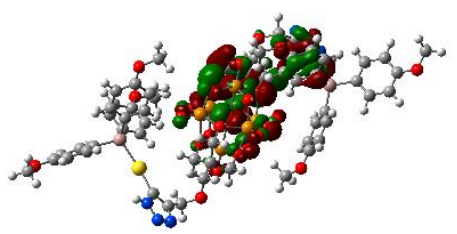

HOMO-1
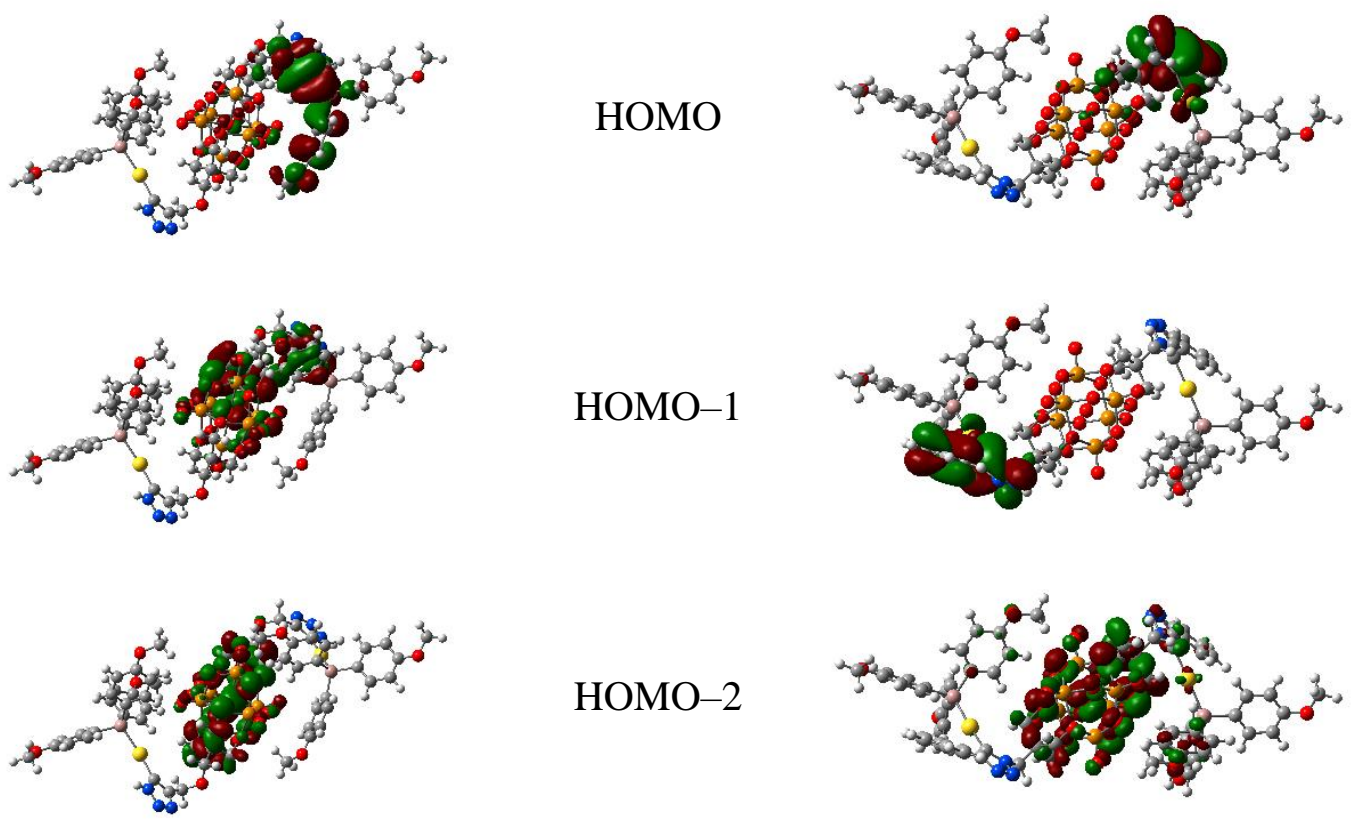

HOMO-2
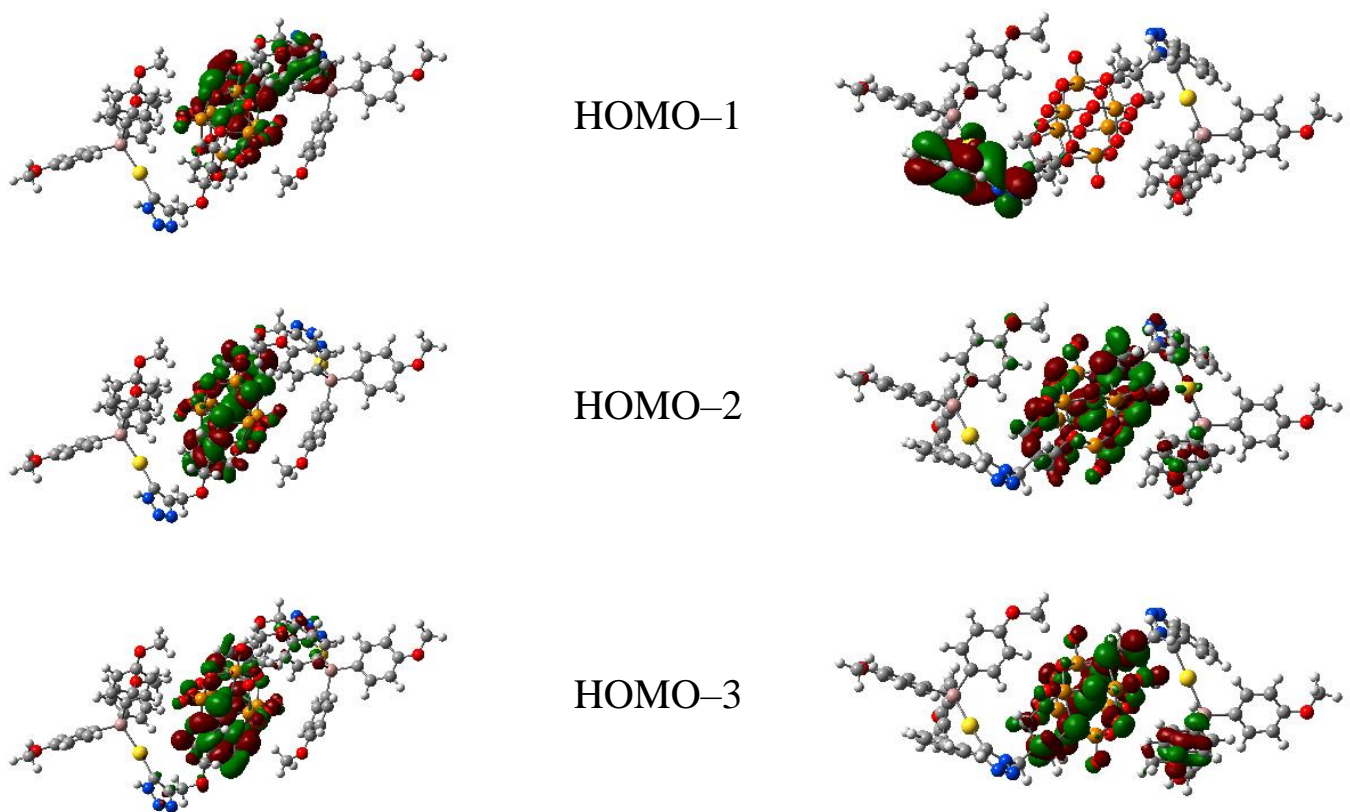

Figure S12. Molecular orbitals of $\mathbf{P O M}_{\mathbf{C}}^{\mathrm{Au}}$ (left column) and $\mathbf{P O} \mathbf{M}_{\mathbf{N}}^{\mathrm{Au}}$ (right column), as obtained by CAM-B3LYP DFT calculations. 


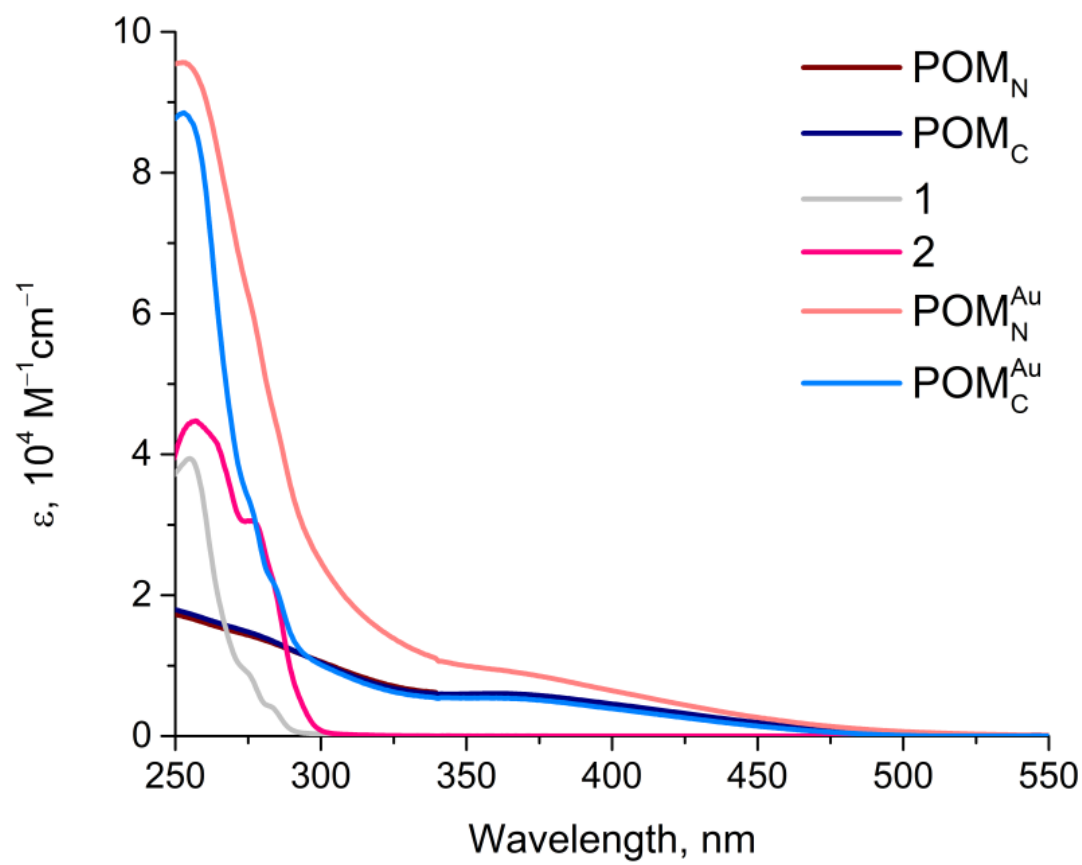

Figure S13. UV/Vis absorption spectra of $\mathbf{P O M}_{\mathbf{N}}^{\mathbf{A u}}$ and $\mathbf{P O} \mathbf{M}_{\mathbf{C}}^{\mathrm{Au}}$ hybrids (DMSO/MeOH = 1/100) and their 'building blocks' $(\mathrm{MeOH} / \mathrm{DCM}=1 / 20)$. 


$$
q
$$

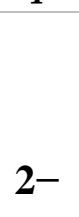

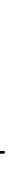

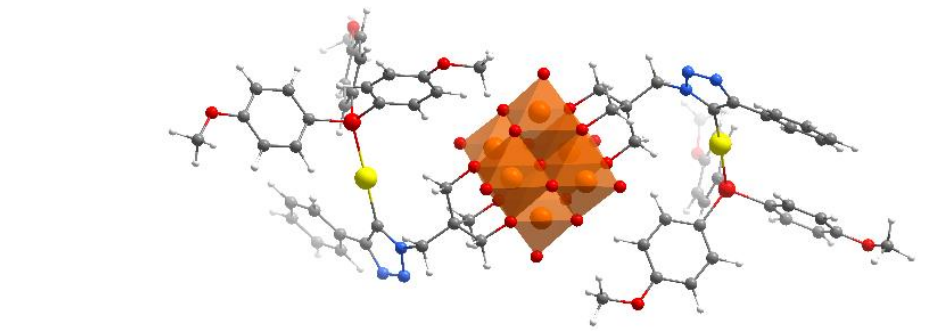

3-
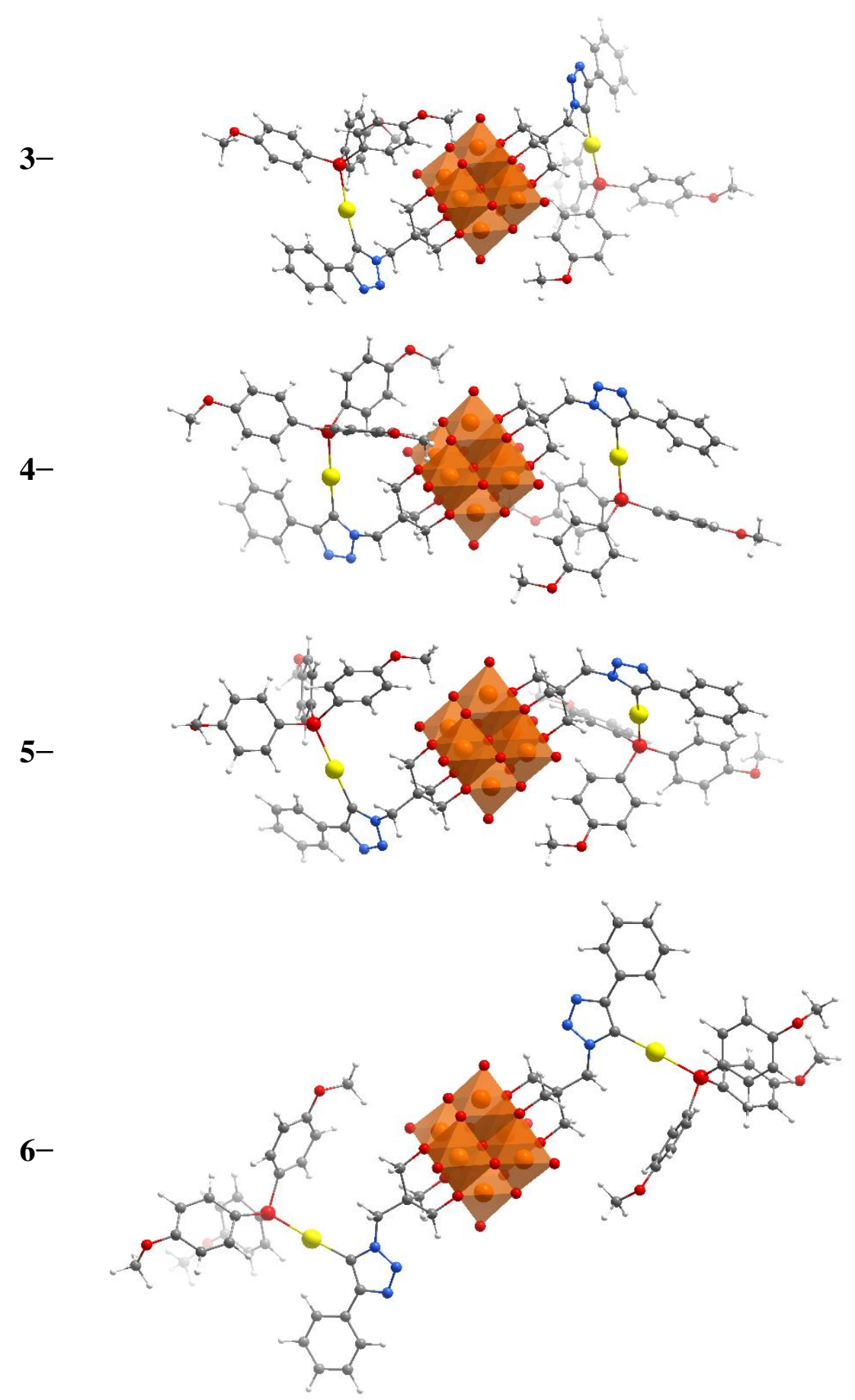

$d_{\mathrm{Au}-\mathrm{Au}}, \AA \quad \boldsymbol{d}_{\mathrm{C}-\mathrm{C}}, \AA$

14.01

27.66

13.77

27.71

13.80

27.95

14.50

28.18

17.77

33.03

Figure S14. Evolution of the $\mathbf{P O M}_{\mathbf{N}}^{\text {Au }}$ hybrid anion structure under upon 'step-by-step' reduction (CAM-B3LYP DFT calculations). The $\mathrm{C}-\mathrm{C}$ distance is the largest carbon-to-carbon distance in the molecule. 


$$
\begin{aligned}
& \text { q } \\
& \text { 2- } \\
& \text { 3- }
\end{aligned}
$$
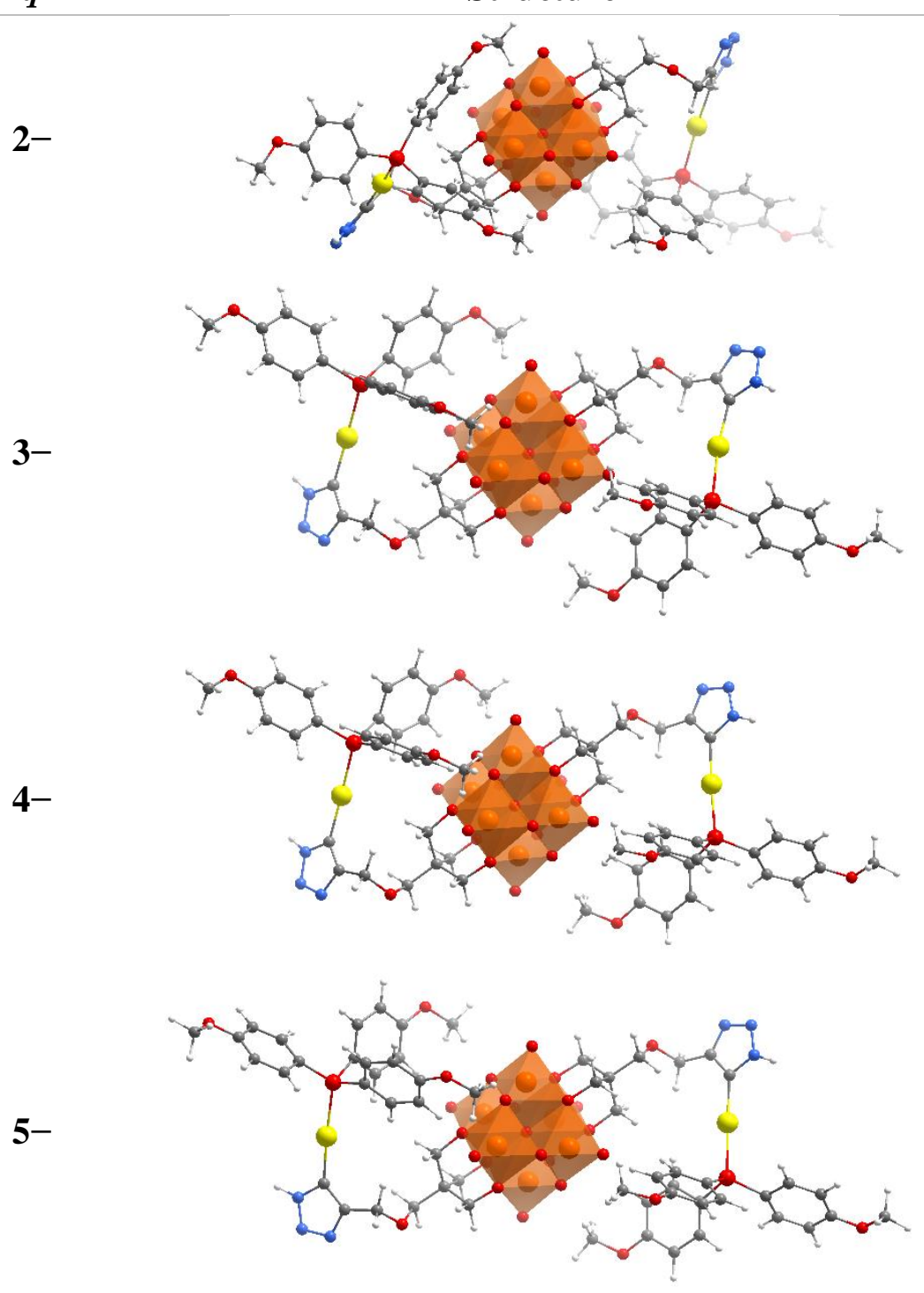

5-

4-

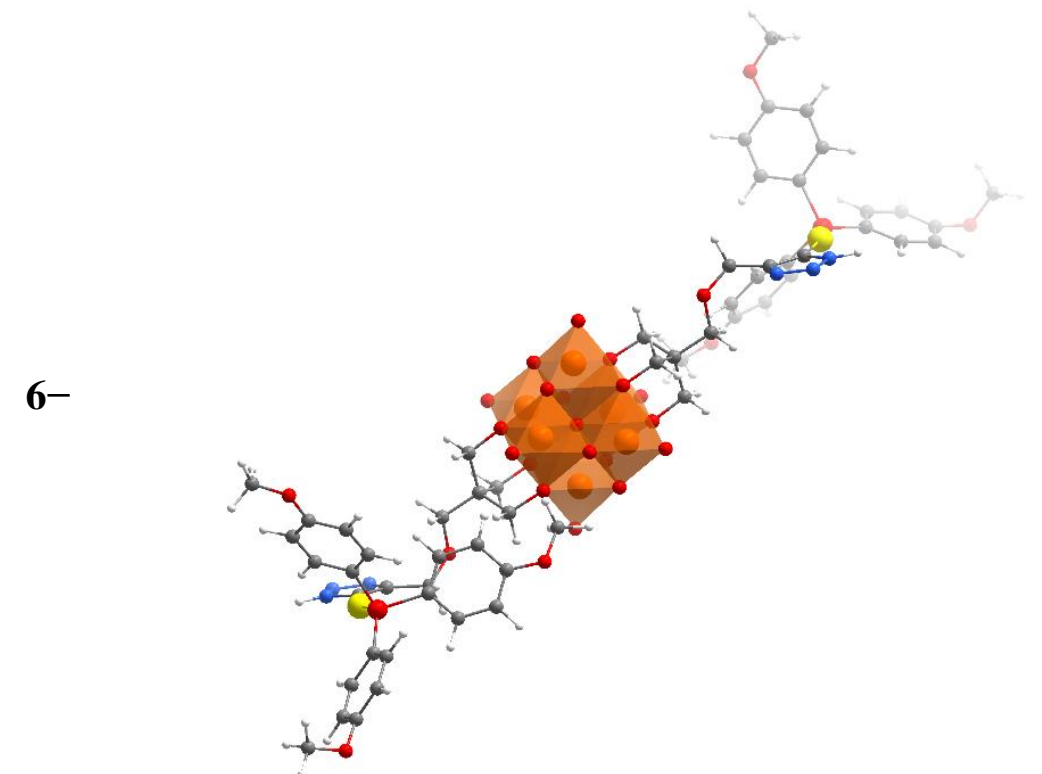

$d_{\mathrm{Au}-\mathrm{Au}}, \AA \quad d_{\mathrm{C}-\mathrm{C}}, \AA$

28.06

15.01

28.16

15.61

29.01

16.70

29.86

20.74

34.11

Figure S15. Evolution of the $\mathbf{P O M}_{\mathbf{C}}^{\mathrm{Au}}$ hybrid anion structure under upon 'step-by-step' reduction (CAM-B3LYP DFT calculations). The $\mathrm{C}-\mathrm{C}$ distance is the largest carbon-to-carbon distance in the molecule. 

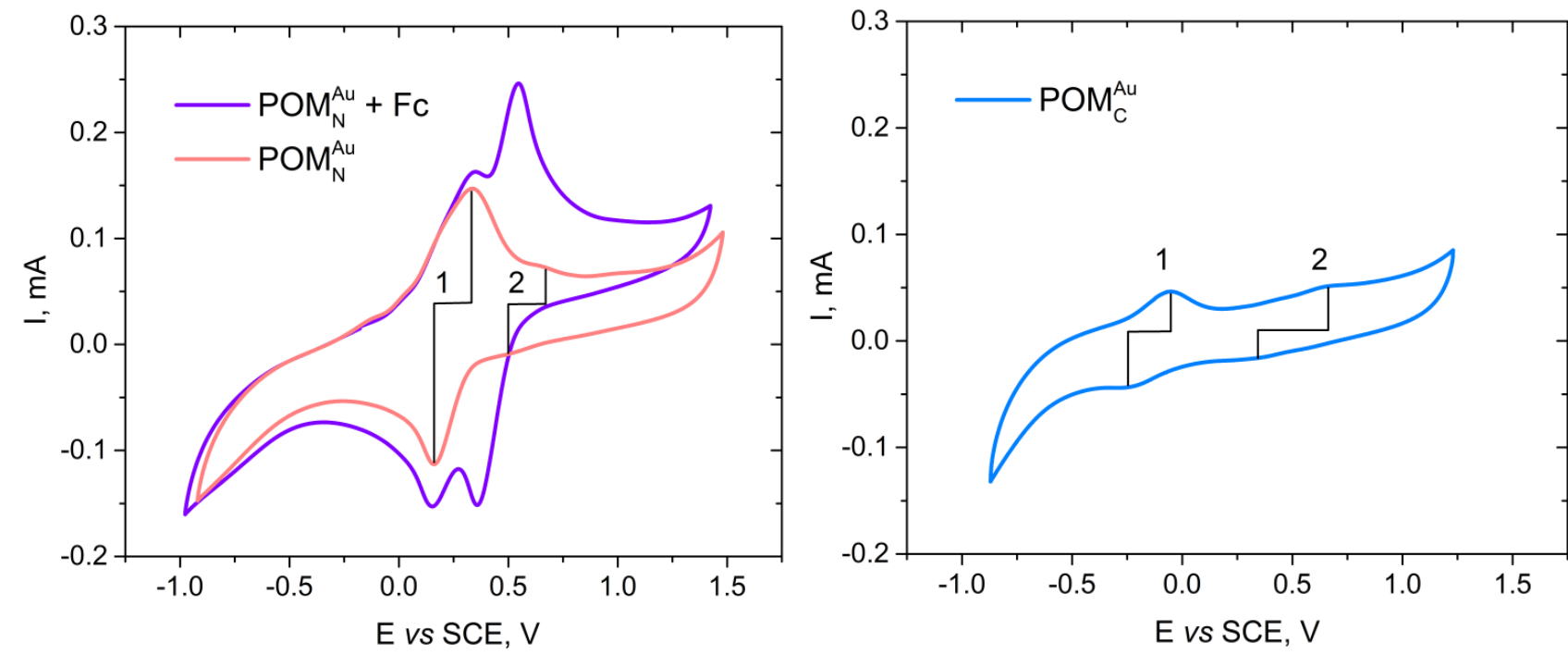

Figure S16. Cyclic voltammograms of $\mathbf{P O M}_{\mathbf{N}}^{\mathbf{A u}}$ and $\mathbf{P O M}_{\mathbf{C}}^{\mathrm{Au}}$ hybrids.

Table S2. Details of cyclic voltammogram measurements of $\mathbf{P O M}_{\mathbf{N}}^{\mathrm{Au}}$ and $\mathbf{P O} \mathbf{M}_{\mathbf{C}}^{\mathrm{Au}}$ hybrids.

\begin{tabular}{|c|c|}
\hline $\mathbf{P O M}_{\mathrm{N}}^{\mathrm{Au}}$ & $\mathrm{POM}_{\mathrm{C}}^{\mathrm{Au}}$ \\
\hline \multicolumn{2}{|c|}{ Sample preparation } \\
\hline $\begin{array}{l}\text { Saturated solution of sample in } 800 \mu \mathrm{L} \\
\text { prepared }\end{array}$ & $\begin{array}{l}\text { Sample completely dissolved in } 800 \mu \mathrm{L} \\
\mathrm{DMF}+100 \mathrm{mM} \mathrm{LiClO}_{4}\end{array}$ \\
\hline \multicolumn{2}{|c|}{ CV conditions } \\
\hline Solution: & $\begin{array}{l}400 \mu \mathrm{L} \text { electrolyte }+ \\
400 \mu \mathrm{L} \text { of sample solution }\end{array}$ \\
\hline Electrode material: & $\mathrm{Pt}$ \\
\hline Reference: & $\mathrm{Fc}$ \\
\hline
\end{tabular}

* All graphs were corrected assuming potential of $\mathrm{Fc}$ at $0.45 \mathrm{~V}$. 


\section{References}

(1) Armarego, W. L. F.; Chai, C. L. L. Purification of Organic Chemicals; 2009.

(2) Uson, R.; Laguna, A.; Laguna, M.; Briggs, D. A.; Murray, H. H.; Fackler, J. P. (Tetrahydrothiophene)Gold(I) or Gold(III) Complexes. In Inorganic Syntheses; 2007; Vol. 29, pp 85-91.

(3) Coates, G. E.; Parkin, C. 621. Gold(I) Alkynyls and Their Co-Ordination Complexes. J. Chem. Soc. 1962, 3220.

(4) Koshevoy, I. O.; Lin, C.-L.; Karttunen, A. J.; Jänis, J.; Haukka, M.; Tunik, S. P.; Chou, P.-T.; Pakkanen, T. A. Highly Luminescent Octanuclear AuI-CuI Clusters Adopting Two Structural Motifs: The Effect of Aliphatic Alkynyl Ligands. Chem. - A Eur. J. 2011, 17 (41), 1145611466.

(5) Beuter, G.; Strähle, J. Cluster Synthesis by Photolysis of $\mathrm{R}_{3} \mathrm{PAuN}_{3}$. Crystal Structure of $\left[\left(\mathrm{Ph}_{3} \mathrm{PAu}\right)_{7} \mathrm{Mo}(\mathrm{CO})_{3}\right] \mathrm{OH}$ and $\left[\left(\mathrm{Ph}_{3} \mathrm{PAu}\right)_{6} \mathrm{AuCO}_{2}(\mathrm{CO})_{6}\right] \mathrm{NO}_{3}$. J. Organomet. Chem. 1989, 372 (1), 67-78.

(6) Jia, H.; Li, Q.; Bayaguud, A.; Huang, Y.; She, S.; Chen, K.; Wei, Y. Diversified Polyoxovanadate Derivatives Obtained by Copper(i)-Catalysed Azide-Alkyne Cycloaddition Reaction: Their Synthesis and Structural Characterization. Dalton Trans. 2018, 47 (2), 577584.

(7) Linnenberg, O.; Kondinski, A.; Stöcker, C.; Monakhov, K. Y. The Cu(i)-Catalysed Huisgen 1,3-Dipolar Cycloaddition Route to (Bio-)Organic Functionalisation of Polyoxovanadates. Dalton Trans. 2017, 46 (45), 15636-15640.

(8) Yanai, T.; Tew, D. P.; Handy, N. C. A New Hybrid Exchange-Correlation Functional Using the Coulomb-Attenuating Method (CAM-B3LYP). Chem. Phys. Lett. 2004, 393 (1-3), 5157.

(9) Andrae, D.; Haussermann, U.; Dolg, M.; Stoll, H.; Preuss, H. Energy-Adjusted Ab Initio Pseudopotentials for the Second and Third Row Transition Elements. Theor. Chim. Acta 1990, 77 (2), 123-141.

(10) Reed, A. E.; Weinstock, R. B.; Weinhold, F. Natural Population Analysis. J. Chem. Phys. 1985, 83 (2), 735-746.

(11) Frisch, M. J.; Trucks, G. W.; Schlegel, H. B.; Scuseria, G. E.; Robb, M. A.; Cheeseman, J. R.; Scalmani, G.; Barone, V.; Petersson, G. A.; Nakatsuji, H.; et al. Gaussian 16, Revision A.03, Gaussian, Inc. Gaussian 16, Revision A.03, Gaussian, Inc., Wallingford CT. Wallingford CT 2016.

(12) Glendening, E. D.; Reed, A. E.; Carpenter, J. E.; Weinhold, F. NBO Version 3.1. NBO Version 3.1. 
(13) Jia, H.; Li, Q.; Bayaguud, A.; She, S.; Huang, Y.; Chen, K.; Wei, Y. Tosylation of Alcohols: An Effective Strategy for the Functional Group Transformation of Organic Derivatives of Polyoxometalates. Sci. Rep. 2017, 7 (1), 12523. 